\title{
Alternative uses for tannery wastes: a review of environmental, sustainability, and science
}

\author{
Cesar Vinicius Toniciolli Rigueto ${ }^{1 *} \mathbb{D}$, Marieli Rosseto ${ }^{1}$, Daniela Dal Castel Krein ${ }^{1}$, Bruna Elisangela Pessini Ostwald ${ }^{2}$, \\ Lillian Avila Massuda², Bárbara Belém Zanella ${ }^{2}$ and Aline Dettmer ${ }^{1,2^{*}}$
}

\begin{abstract}
The manufacture of leather covers a wide productive chain and beyond contributes to the economic flow. The various stages of leather processing result in high volumes of solid waste. In Brazil, a daily generation of 375 tons of solid waste is estimated, and landfills are still the most used route to its destination. In this review, emphasis will be given to researches that have sought alternatives for the use of solid waste from the tannery industry. Among the main applications of solid tannery wastes, the following stand out production of adsorbent materials, biodiesel, biogas, biopolymers, applications in agriculture and other applications involving extraction/recovery of compounds of industrial/commercial interest, isolation of microorganisms and production of enzymes and applications in the animal diet. In each alternative of waste application, the technologies used, the opportunities, and the challenges faced are mentioned. We hope that this review can provide valuable information to promote the broad understanding of the possibilities that tannery solid wastes has for the development of biodegradable and agricultural products, wastewater treatment, extraction of compounds of industrial and commercial interest, among others.
\end{abstract}

Keywords: Leather, Adsorption, Biodiesel, Biogas, Biopolymers, Agriculture

\section{Introduction}

Solid residues are by-products from human and industrial activities, associated with negative impacts on human beings and the environment when disposed of incorrectly. The reduction of the generation of this waste and its proper management, therefore, become imminent challenges for government agencies [1].

Brazil has the second-largest cattle herd in the world, with 232 million head and increasing productivity [2]. According to the Center for the Tanning Industries of Brazil, the leather trade represents a strong industrial sector in the country, mainly in the southern region, which has been generated considerable volumes of solid

\footnotetext{
* Correspondence: cesartoniciolli@gmail.com; alinedettmer@upf.br 'Postgraduate Program in Food Science and Technology (PPGCTA), University of Passo Fundo (UPF), Faculty of Agronomy and Veterinary Medicine (FAMV), Passo Fundo, RS, Brazil

Full list of author information is available at the end of the article
}

waste. More recent data show that in 2019 Brazil exported approximately 179 million $\mathrm{m}^{2}$ of hides and skins [3].

Hide is a natural material composed of collagen fibers linked to a three-dimensional structure, and for conservation purposes, improving the physical, chemical, and biological properties, hide parts are subjected to the tanning process [4]. Besides, several other mechanical steps are necessary to standardize the thickness of the leather, generating large amounts of solid wastes, such as hides and skins having and trimmings, fats, buffing dust, and sludge from effluents [5].

The solid wastes generated, mainly, in the shaving and cutting stages are considered by the Brazilian standard ABNT NBR10.004 [6] as Class I dangerous, due to their toxicity according to the leaching test according to ABNT NBR 10.005 [7]. Each piece of tanned leather 
results in 2 to $3 \mathrm{~kg}$ of chromium-tanned shavings and consequently approximately 375 tons of solid tannery wastes in Brazil are generated daily [8].

Disposal in landfills is still the most used way to manage leather waste in Brazil, as it is faster and more economical, not being an environmentally friendly solution, since the material confined in the ditches generates an environmental liability to be monitored for years, in addition to the depletion of landfills due to the high volume generated, requiring the construction of new landfills. In the state of Rio Grande do Sul, for example, which is the largest leather producing state in the country, by 2015 there were 42 industrial landfills [9]. However, Kipper [10] found that the residues obtained in the stage of leather thickness adjusting and lime and wetblue shavings decreased considerably between 2003 and 2013 , which is possibly related to the use of these residues in the production of fertilizers and the manufacture gelatin or animal feed, respectively.

In this context, to reconcile science, technology, and sustainability, applications beyond landfill disposal have been studied, aiming an alternative use of tannery wastes, in addition to reducing the impact of the production process [11-17]. The wastes from the production of leather have also been used in the production of biodiesel [18-20], biogas [21-23], biopolymers [24-26], adsorbent materials [27-29], agriculture applications [30-32], and others.

Thus, the objective of this study was to carry out a review addressing the main methods for using tannery solid wastes, covering the technologies used and the opportunities, in addition to the challenges faced by each technique.

\section{Methodology}

The survey of articles was based on the search for documents according to the insertion of certain terms in the Scopus database. At first, articles were searched that addressed in the title, abstract and keywords the terms "Tannery" AND "Waste", and from the analysis of the main applications studied for leather waste, the topics of this article were selected. The search period was from 2000 to 2020.

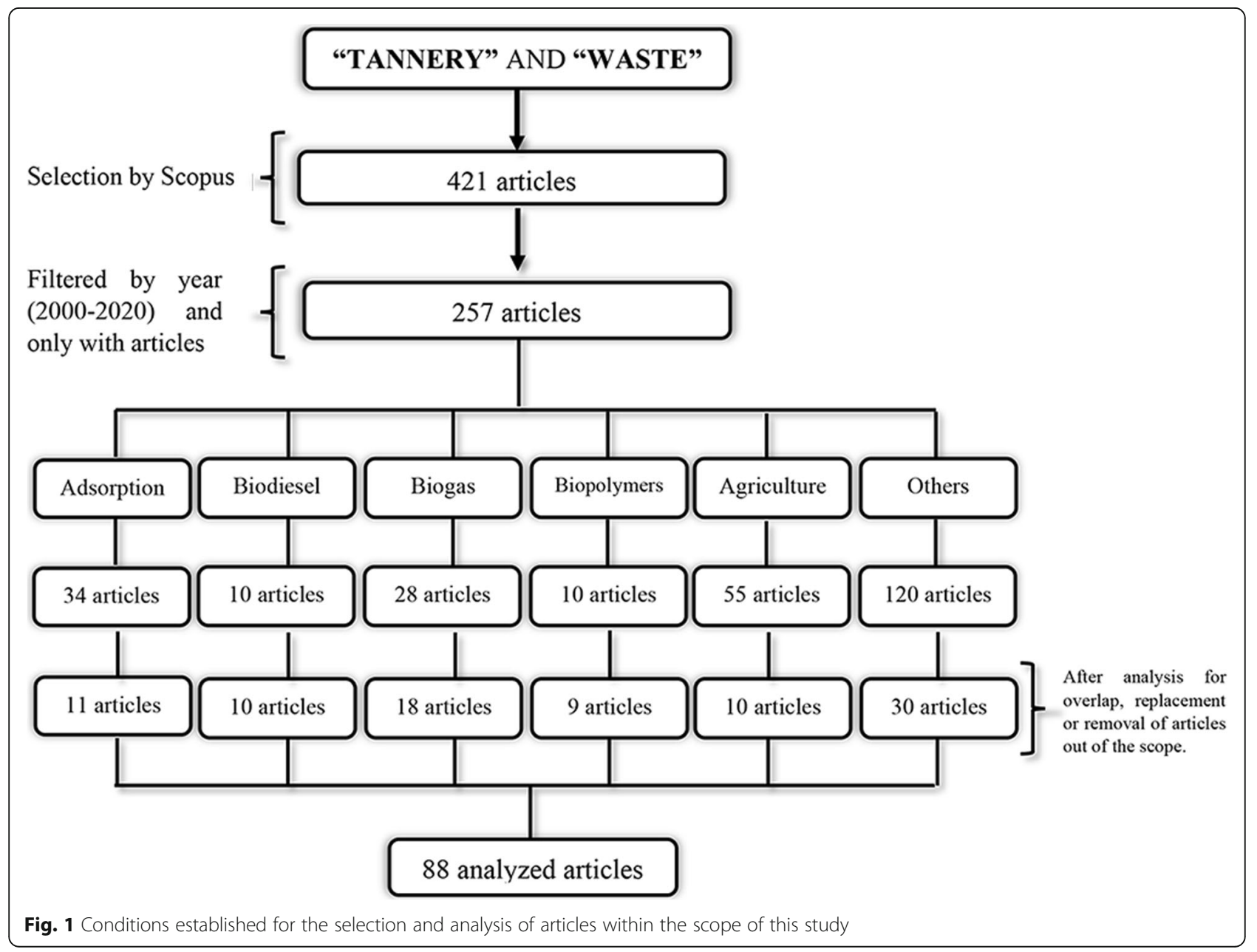


The results of the preliminary Scopus searches were analyzed to eliminate articles with overlapping content, to recategorize certain articles to the method considered most appropriate based on its content, and almost important, to exclude articles that did not fall within the scope of this paper. Figure 1 presents a flowchart that summarizes the methodology of this study.

From the surveys and content analysis, the selected articles were explored by the authors using the "Bibliometrix" tool of RStudio software version 7.6, as a way to systematize the state of the art and, mainly, to weave discussions that generate new knowledge about the applications of tannery wastes.

According to the bibliometric analysis carried out, it is noted that the interest in the topic of tannery waste is growing, with a greater peak of publications in 2019. Still, Brazil stands out as the 2nd country that publishes more articles focused on thematic of tannery waste (Fig. 2a and b).

Moreover, in the study carried out by Jiang et al. [33] it is estimated that the percentage of articles involving the theme of leather solid wastes has increased by $76.62 \%$ in the period 1969 to 2015 , with this trend being more pronounced in 2006, indicating that leather waste treatment become a topic of growing interest.

Also, in WordCloud generated with the main keywords included in the articles that address the theme of tannery waste (Fig. 2c), it is noted that the words are directly related to opportunities for the use of leather waste, such as biogas production, fertilizers, biopolymers, and adsorption processes.

\section{Main applications studied for tannery wastes}

Based on the themes presented in WordCloud (Fig. 2c), the topics covered in this review are the use of leather waste in the production of adsorbent materials, biodiesel, biogas, biopolymers, applications in agriculture and other general applications, which mainly cover, extraction/recovery of compounds of industrial/commercial interest, isolation of microorganisms and production of enzymes and use in the animal diets. In each topic, the main promising results found by each technique are listed, as well as the challenges that still need to be overcome.

\subsection{Adsorption}

Adsorption is a relatively simple technique and commonly used in wastewater treatment, relating low cost and removal efficiency depending on the adsorbent material used [34].

The adsorbent materials used in the adsorption processes must-have characteristics such as high selectivity, high surface area and high adsorption capacity, combined with long useful life and the possibility of reuse
[35]. The possibility of producing adsorbents from residues from the industrial or agricultural sector, as known as biosorbents, should also be considered, expanding the application possibilities [36].

In this context, industries have encouraged obtaining adsorbents from alternative precursors, such as sludge from tannery wastewater treatment, for example. This residue has a carbonaceous nature, being suitable to produce activated carbon, reducing the volume of sludge and generating a low-cost adsorbent that can be used by the industry itself in the treatment of effluents [37].

Palani et al. [27] produced activated carbon from tannery fleshing wastes, by pyrolysis process, obtaining greater porosity (amount of mesopores and macropores), a greater number of surface functional groups and thermal resistance compared to commercial activated carbon. The maximum chromium (VI) removal achieved was around 97\%. Amalraj and Pius [4] developed activated carbon from vegetable-tanned leather trimmings to remove three basic dyes, resulting in an adsorbent material capable of removing over $90 \%$ of the investigated dyes. The solid wastes obtained from the shaving leather operation were also studied in the removal of dyes used in the leather dyeing, and showed promising adsorbents in the reduction of color and the presence of organic and inorganic contaminants, allowing the reuse of effluents from the leather industry [29, 38]. Similarly, Arcibar-Orozco et al. [39] prepared activated carbons from chromium-tanned leather shavings, by using a low temperature, $\mathrm{ZnCl}_{2}$-activated process. The prepared materials displayed a higher affinity, and about $50 \%$ of the adsorption capacity, of a commercial activated carbon for Acid Black 210 dye, with maximum experimental adsorption capacity of $44.4 \mathrm{mg} / \mathrm{g}$.

Adsorption studies using aqueous solutions are extremely useful for understanding the interaction mechanisms between the contaminant and the adsorbent material. However, batch tests cannot be applied directly at the industrial level, since the actual effluents contain in their composition several other chemical compounds from industrial processes, which can interfere with the adsorption efficiency predicted in the tests with monocomponent solution, and therefore, experiments using real effluents should also be investigated [28].

Table 1 presents studies that used the solid wastes from the tannery industry in the production of adsorbents, as well as the values of the main parameters involved in the process and their respective removal capabilities.

The variables temperature, $\mathrm{pH}$, concentration of the contaminant and adsorbent directly influence the adsorption process, which may interfere in the way in which the adsorbate molecule will find an active place in the adsorbent material, where it will be retained. Thus, 
a

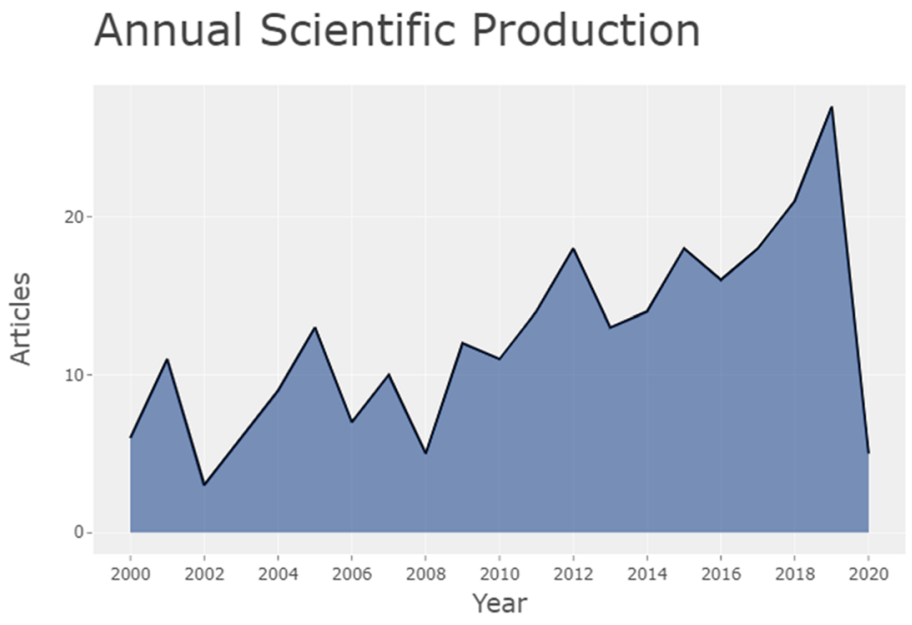

b

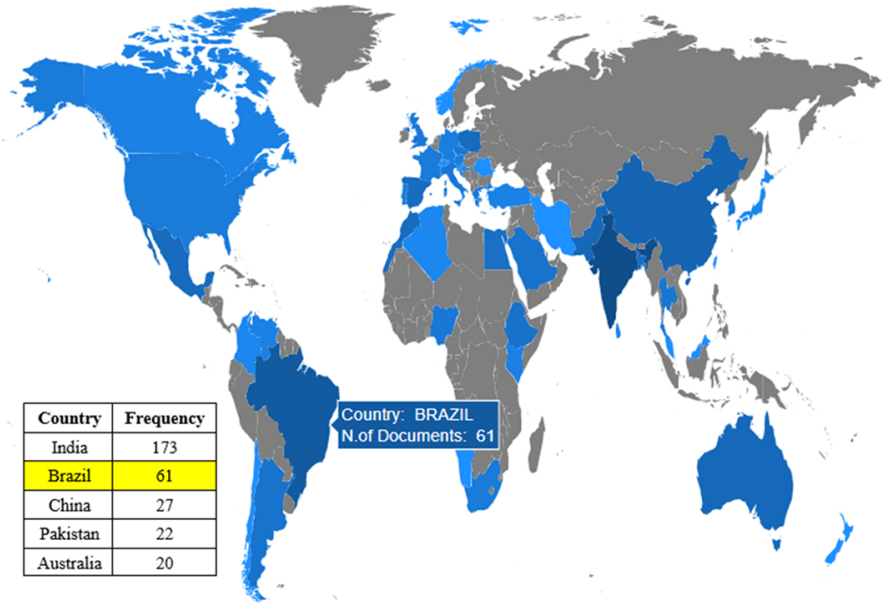

C

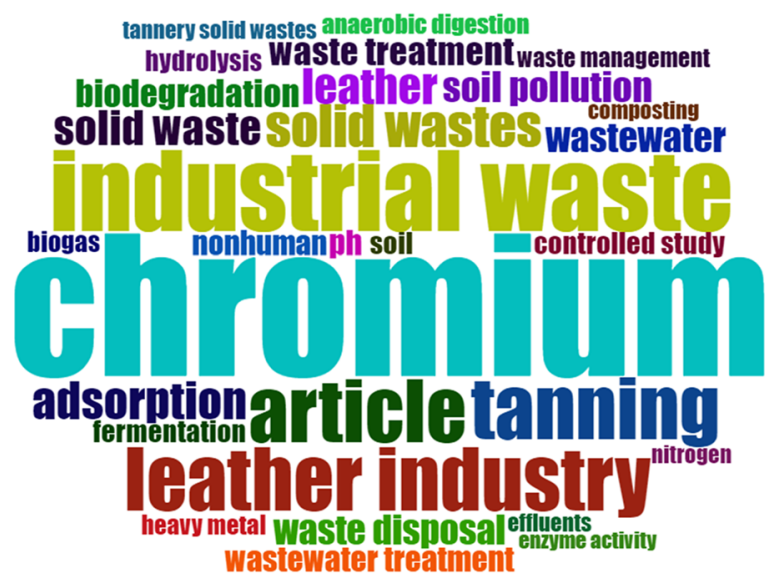

Fig. 2 a) Annual global scientific production of articles that address the theme tannery waste, $\mathbf{b}$ ) Scientific production by country of articles that address the tannery waste theme, and c) WordCloud with the most cited words in the keywords of the articles studied

the search for the optimization of these variables is essential to achieve the maximum adsorption capacity of the studied material [28]. It is observed in Table 1 that the dyes adsorption tests were conducted at acidic or slightly acidic $\mathrm{pH}(2.5-5.5)$. When the $\mathrm{pH}$ decreases, the amine groups present in the collagen of the tanned 
Table 1 Studies that used tannery wastes from various stages of leather processing as an adsorbent material

\begin{tabular}{|c|c|c|c|c|c|c|}
\hline \multirow[t]{2}{*}{ Adsorbent used } & \multirow[t]{2}{*}{ Contaminant } & \multirow[t]{2}{*}{ (mg/g) } & \multirow[t]{2}{*}{$\begin{array}{l}\text { Removal } \\
(\%)\end{array}$} & \multicolumn{2}{|c|}{$\begin{array}{l}\text { Experimental } \\
\text { conditions }\end{array}$} & \multirow[t]{2}{*}{ Reference } \\
\hline & & & & $\mathrm{pH}$ & $\begin{array}{l}\text { Equilibrium } \\
\text { time (min) }\end{array}$ & \\
\hline \multirow[t]{2}{*}{ Activated carbon from cattle hair waste } & Acid brown 414 dye & - & 71.06 & 3.5 & 1440 & {$[40]$} \\
\hline & Acid orange 142 dye & - & 73.05 & & & \\
\hline $\begin{array}{l}\text { Activated carbon from tannery fleshing } \\
\text { waste }\end{array}$ & Chromium (VI) & $60.8^{a}$ & $\geq 97.0$ & 3.0 & 1440 & {$[27]$} \\
\hline \multirow[t]{2}{*}{ Solid chromium-tanned wastes } & Acid red 357 & $239.9^{a}$ & - & 2.5 & - & [41] \\
\hline & Acid black 210 & $138.1^{\mathrm{a}}$ & - & & - & \\
\hline Solid chromium-tanned wastes & $\begin{array}{l}\text { Simulated effluent from the end of the wet blue } \\
\text { leather dyeing stage containing Acid red } 357 \text { dye }\end{array}$ & $148.2^{\mathrm{a}}$ & 58 & 3.0 & 60 & {$[42]$} \\
\hline Leather shaving waste & $\begin{array}{l}\text { Simulated effluent from the end of the wet blue } \\
\text { leather dyeing stage containing Acid red } 357 \text { dye }\end{array}$ & $24.74^{\mathrm{a}}$ & 87.37 & 3.75 & 60 & [28] \\
\hline \multirow{3}{*}{$\begin{array}{l}\text { Activated carbons from tannery leather } \\
\text { scraps }\end{array}$} & Methylene blue dye & $15.0^{\mathrm{a}}$ & - & - & - & [43] \\
\hline & Phenol & $80.0^{a}$ & - & - & & \\
\hline & Chromium (VI) & $0.10^{\mathrm{a}}$ & - & 7.0 & & \\
\hline \multirow{3}{*}{$\begin{array}{l}\text { Activated carbon from from vegetable- } \\
\text { tanned leather trimmings }\end{array}$} & Rhodamine B dye & $43.44^{b}$ & 97.72 & 3.0 & 60 & {$[4]$} \\
\hline & Methylene blue dye & $87.64^{b}$ & 96.85 & 11.0 & & \\
\hline & Malachite green dye & 159.49 & 91.82 & 11.0 & & \\
\hline \multirow{3}{*}{$\begin{array}{l}\text { Chromium-tanned leather waste from } \\
\text { shaving step }\end{array}$} & Acid yellow 194 dye & $550.0^{a}$ & - & 2.5 & 60 & [29] \\
\hline & Acid red 357 dye & $413.9^{\mathrm{a}}$ & - & & $\cong 120$ & \\
\hline & Acid black 210 dye & $156.6^{\mathrm{a}}$ & - & & $\cong 120$ & \\
\hline \multirow{2}{*}{$\begin{array}{l}\text { Surface modified cashew husk-based } \\
\text { tannery residual biomass }\end{array}$} & Chromium (VI) & $177.0^{b}$ & - & 2.0 & - & [44] \\
\hline & Rhodamine B dye & $213.0^{b}$ & - & 3.5 & - & \\
\hline \multirow[t]{3}{*}{ Waste sludge from the tannery industry } & Methylene blue dye & $454.5^{b}$ & - & - & 1440 & {$[37]$} \\
\hline & Phenol & $172.4^{b}$ & - & - & 240 & \\
\hline & Chromium (VI) & $109.9^{b}$ & - & 2.0 & 120 & \\
\hline \multirow[t]{4}{*}{ Wet-blue waste } & Drimaren red dye & $121.4^{\mathrm{a}}$ & & 5.5 & - & {$[45]$} \\
\hline & Cibacron yellow dye & $135.4^{\mathrm{a}}$ & - & & - & \\
\hline & Procion blue dye & $118.8^{a}$ & - & & - & \\
\hline & Indigo carmine dye & $109.8^{\mathrm{a}}$ & - & & - & \\
\hline
\end{tabular}

leather are protonated in the form $\mathrm{NH}^{3+}$, and the dyes of an anionic nature are easily attracted to the surface of the tannery waste, with adsorption occurring [46].

For adsorption of metals such as Chromium (VI) for example, the ideal $\mathrm{pH}$ for removal is close to 2.0 , this effect is explained due to the different forms of ionization of chromium, in which the increase in the availability of protons on active sites, causes the positively charged surface to attract anions and, as hexavalent chromium presents itself as chromate, in the anionic form $\left(\mathrm{Cr}_{2} \mathrm{O}_{4}{ }^{2-}\right)$, the positive charge on the adsorbent surface favors the bonding with $\mathrm{Cr}$ (VI). The point of zero charge of activated carbon produced from leather waste in Palani et al. [27] study was 7.6, thus confirming the interaction of the surface of the positively charged material with chromium (VI) in its anionic form. In the study by Montoya-Suarez et al. [43] the experiments were conducted at $\mathrm{pH}$ 7.0, a factor that caused the lowest Chromium (VI) adsorption capacity $(0.10 \mathrm{mg} / \mathrm{g})$ compared to the other studies.

The different ways of leather tanning can also influence the adsorption process. Piccin et al. [29] found that the dyes removal capacity by vegetable-tanned leather is inferior to chromium-tanned leather in all studied $\mathrm{pH}$ conditions, although both follow the same reduction trend as the $\mathrm{pH}$ increases. Gutterres [11] explains that this phenomenon occurs because the vegetable tanning molecule is composed mainly of phenolic compounds, 
such as tannins, which come from plants and linked by hydrogen bonds to the carboxylic and amino groups in the leather, thus the number of available sites is reduced, as well as the adsorption capacity.

Kinetic and equilibrium data are also essential for analysis and understanding of the mechanisms involved in the adsorption of contaminants, providing information about the capacity and speed adsorption, respectively [47]. Most of the studies that perform mathematical modeling of the experimental data presented in Table 1, obtained the best kinetic and isothermal adjustments, in the pseudo-second order and Langmuir models, respectively. The tendency to adjust to these models suggests a homogeneous nature of the materials used, in addition to the adsorption process governed by monolayer chemisorption.

However, even with promising application trends as a biosorbent, further studies are still needed using tannery wastes or activated carbon obtained from them, to treat real effluents from the final stages of industrial processing, to ensure effective removal in multicomponent systems. Rigueto et al. [36] point out that among the biggest challenges that need to be overcome for applications of alternative adsorbent materials, the life cycle stands out, which include considerations about the possibility of material regeneration, in addition to economic viability combined with good removal capacity, since this last parameter is often reduced at lower concentrations of certain contaminants in real effluents.

\subsection{Biodiesel}

Discussions about alternative sources to produce biofuels remain constant since biodiesel is an accessible alternative both in terms of trade and in the possibilities of using raw materials. The most common sources are soybeans, corn, cellulose, algae oil and sugar cane, however, these raw materials, food sources, are removed from the world's food and their oils are considered expensive [48].

Brazil stands out in the production of hides and leather and thus generates large amounts of waste, which appear as an alternative for the production of biodiesel, since they have a high-fat content, varying, for example, from 40 to $60 \%$ in fleshing bovine wastes. Therefore, it is possible to create a product with added value and with an environmental bias, due to the reduction of these residues discarded in the environment [49]. In Brazil, some companies already produce biodiesel from the fat of bovine leather.

The principle of biodiesel production is based on the mixture of fatty acid esters, obtained by trans esterifying vegetable oils or animal fats with low molecular weight alcohol, with glycerol as a by-product. Normally, in the transesterification reaction of triglycerides (formed from the union of 3 fatty acids) with methanol, a homogeneous alkaline catalyst is used, which requires raw materials with a low fatty acid content, up to a maximum of $1 \mathrm{mg} \mathrm{KOH} / \mathrm{g}$, as shown in Fig. 3 - Reaction A.

Transesterification can be classified as catalytic and non-catalytic. In catalytic, it is common to use basic or acid catalysts, most used the basic ones. In non-catalytic use of enzymes, however, this process has high production value and difficulty in reusing enzymes, separation problems, among others [50].

Animal fats regularly maintain an amount of $5-30 \%$ fatty acids, which leads to the formation of soap, making separation more difficult. Booramurthy et al. [19] studied the composition of fatty acids present in the fat from the tannery wastes (Table 2), verifying that they have a greater amount of fatty acids compared to vegetable oil.

A solution to this problem is the addition of a pretreatment (Fig. 3 - Reaction B), which consists of the esterification of methanol and sulfuric acid, as a catalyst, where after this method, the fat can be transesterified by the conventional process to obtain methyl esters [49].

In the pretreatment process, there are two main steps: refining and removing fatty acids (deacidification). At the refining point, it is possible to decrease the content of water, ash, the number of acids or, possibly, the nitrogen content. In the case of deacidification, a physical extraction process occurs, usually using methanol [51].

Šánek et al. [20] analyzed the pretreatment of fat using alkaline methanolic solutions (using methylammonium tetrahydroxide) instead of pure methanol and obtained a reduction of $98.4 \%$ in fatty acid levels, proceeding to transesterification and producing biodiesel that meets most of the requirements of the European standard EN 14214 of 2012. Table 3 shows different studies where biodiesel was produced from tannery waste.

The values of density and viscosity have a great influence on the circulation, injection, and preservation of fuel in the engines, however, satisfactorily, both diesel and biodiesel present close values in density. The same does not happen with viscosity, which remains high compared to petroleum diesel, which can cause incomplete combustion and deposition in the engine [53]. The flash point is used as an indication of safety, both in storage and transport. Therefore, biodiesel with a flash point above room temperature, free from methanol or ethanol, has easier transport and storage than one with the presence of these compounds. When it has methanol or ethanol, its flash point drops, on average, from 10 to $14{ }^{\circ} \mathrm{C}$, making storage and transportation difficult [54].

Altun [55] studied the use of biodiesel from tannery residues and applied it to an injection engine to analyze its behavior compared to conventional diesel. A similarity was found in the parameters of emission and performance. A promising alternative, because also, its 


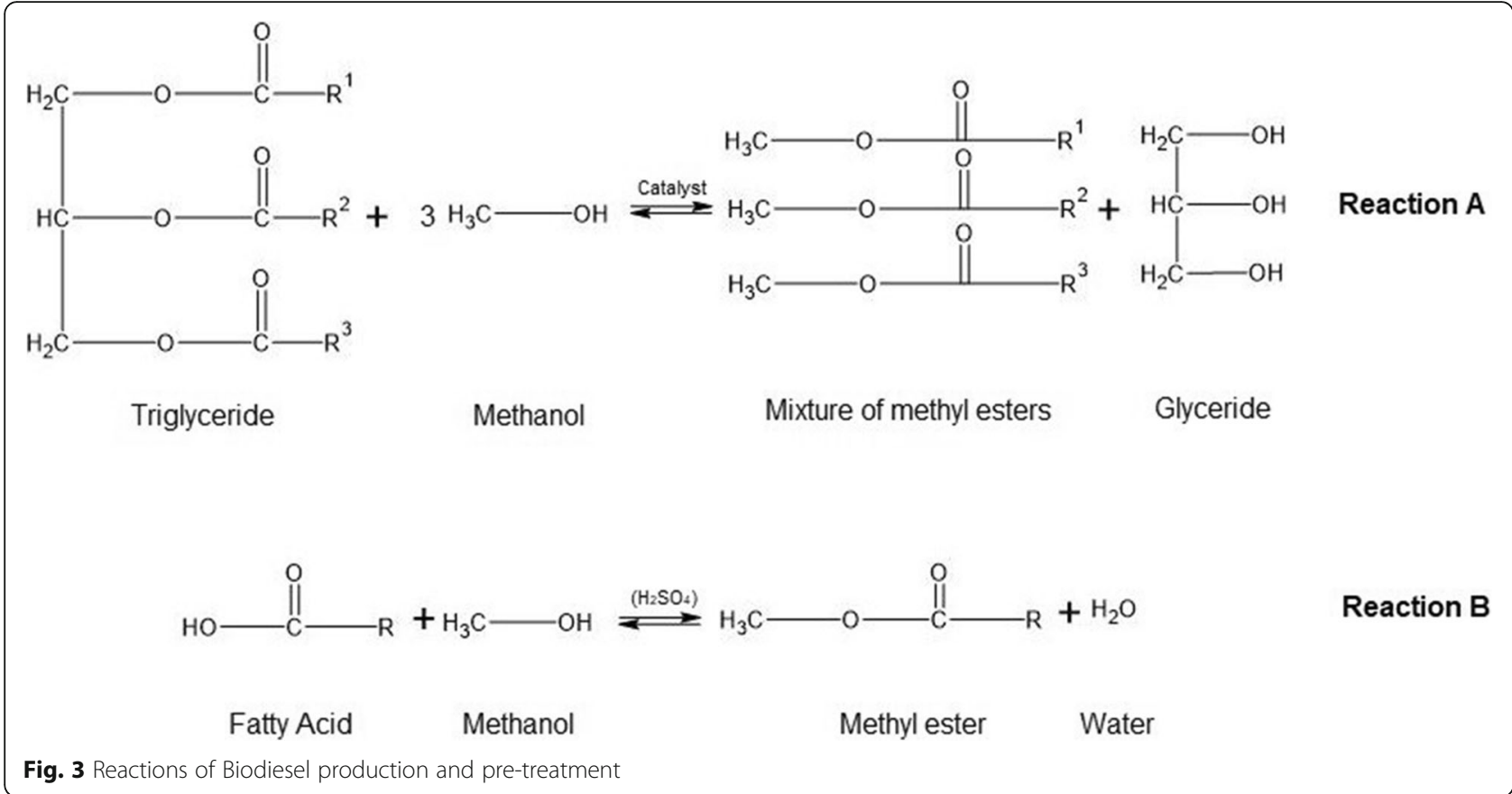

number of cetane or cetanage is higher than in fuels from oil, resulting in better combustion [56]. However, its cloud point is considered high, which at lower temperatures, can cause an increase in NOx emissions, in addition to possible solidification of biodiesel, since the fluid does not flow more freely $[18,57]$.

According to the National Agency of Petroleum, Natural Gas and Biofuels (ANP) of Brazil [58], the value of water in biodiesel should remain at a maximum of 500 $\mathrm{mg} / \mathrm{kg}$, since the amount greater than this, biodiesel can become corrosive, affecting the efficiency and life of the engine. The acid value, on the other hand, remains at a maximum of $0.5 \mathrm{mg} \mathrm{KOH} / \mathrm{g}$, according to ABNT NBR 14448 , a factor that also influences corrosion and storage stability. It is worth mentioning that these values also follow European (EN/ISO) and American (ASTM) regulations, as shown in Table 4.

Table 2 Main fatty acids present in the fat extracted from tannery wastes

\begin{tabular}{lll}
\hline Type of Fatty Acid & Carbon Chain & $\%$ \\
\hline Miristic Acid & C14:0 & 4.18 \\
Palmitic Acid & C16:0 & 24.22 \\
Steric Acid & C18:0 & 30.23 \\
Oleic acid & C18:1 & 37.76 \\
Linoleic acid & C18:2 & 2.78 \\
Linolenic Acid & C18:3 & 0.17 \\
Araquic Acid & C20:0 & 0.20 \\
Undetectable & - & 0.46 \\
\hline
\end{tabular}

Source: Adapted from [19]
In general, the use of waste from the leather industry proves to be a very promising alternative to produce biodiesel, once certain fundamental parameters analyzed, such as those presented in Table 4, adapting to the current regulations. Booramurthy et al. [19] verified that the contents of sulfated ash and carbon residue also conform to the standards of ASTM D 874 [62] and ASTM D 4530 [63], respectively.

Among the main challenges in the production of biodiesel from leather waste, the formation of soap in the transesterification stands out, which requires a pretreatment, viscosity, and cloud point. Thus, research is needed to seek improvements in these parameters, since the use of this abundant waste as an alternative raw material, can help supply a percentage of the biodiesel market demand, reducing the use of food sources.

\subsection{Biogas}

Since the industrial revolution, the $\mathrm{CO}_{2}$ content in the atmosphere is constantly increasing and is estimated to reach $750 \mathrm{ppm}$ by the end of this century [64]. As $\mathrm{CO}_{2}$ stops the infrared radiation from the sun and thus increases the temperature of the earth, causing the greenhouse effect. This effect has many implications and requires the search for new alternative sources of energy and biogas production appears as a strong renewable energy source [65].

Biogas as a representative of renewable energy sources [66] can be obtained through the biological degradation of various organic waste, such, as chicken [63], swine [67], bovine [68], manure and municipal solid waste [69] 
Table 3 Comparison of studies involving biodiesel from tannery waste, petro-diesel, and B100

\begin{tabular}{|c|c|c|c|c|c|c|c|}
\hline & \multirow[t]{2}{*}{ Units } & \multicolumn{3}{|l|}{$[52]$} & \multirow[t]{2}{*}[20]{} & \multirow[t]{2}{*}{ [19] } & \multirow[t]{2}{*}[18]{} \\
\hline & & $\overline{\text { Petro-diesel }^{c}}$ & $\mathrm{~B} 100^{\mathrm{d}}$ & TW $^{\mathrm{e}}$ & & & \\
\hline Density at $15^{\circ} \mathrm{C}^{\mathrm{a}}$ or $30^{\circ} \mathrm{C}^{\mathrm{b}}$ & $\mathrm{kg} / \mathrm{l}$ & $0.834^{\mathrm{a}}$ & $0.86-0.9^{b}$ & $0.855^{\mathrm{b}}$ & $0.878^{\mathrm{a}}$ & - & $0.87^{\circ}$ \\
\hline Viscosity at $40^{\circ} \mathrm{C}$ & $\mathrm{mm}^{2} / \mathrm{s}$ & $1.9-4.1$ & $1.9-6$ & 4.2 & 4.7 & 4.4 & 4.6 \\
\hline Flash Point & ${ }^{\circ} \mathrm{C}$ & $60-80$ & $100-170$ & 160 & 161.5 & 153 & 150 \\
\hline Cloud Point & ${ }^{\circ} \mathrm{C}$ & $-15-5$ & $-3-12$ & 4 & - & 16 & 8 \\
\hline Cetane Number & $\mathrm{CN}$ & $48-52$ & $48-65$ & - & 67.4 & 62 & 58 \\
\hline Water & $\%$ & 0.05 & 0.05 & $<0.01$ & - & 0.05 & - \\
\hline Acidity & $\mathrm{mg} \mathrm{KOH} / \mathrm{g}$ & 0.5 & 0.5 & 0.07 & 0.16 & 0.4 & 0.3 \\
\hline
\end{tabular}

${ }^{a}$ Describing the temperature $15^{\circ} \mathrm{C}$, referring to the different temperatures in which density was determined

${ }^{\mathrm{b}}$ Describing the temperature $30^{\circ} \mathrm{C}$, referring to the different temperatures in which density was determined

'Petro-diesel: diesel from a petrochemical source only

${ }^{d}$ B100: biodiesel made from exclusively non-petrochemical sources

Biodiesel obtained from tannery waste

in addition to the use of enzymes and microorganisms [70]. Tannery's waste can also be used to obtain biogas [71]. It is common to submit tannery waste to some pretreatment before anaerobic digestion was performed. Table 5 presents the different pretreatments to increase biogas production.

The leather industry produces large quantities of waste, where animal fat represents the most important waste with a high thermal value. These residues have a high protein content, where it creates the opportunity to use an anaerobic digester for their treatment [71]. The digestion process consists of hydrolysis acidogenesis, acetogenesis and methanogenesis, and each stage is a function of the metabolic condition of the various microorganisms [75].
Agustini et al. [18] concluded that the variables $\mathrm{pH}$, TS, VC, COD, and TKN directly influence the obtention and can also interfere in the burning yield of biogas. Although the $\mathrm{pH} 7.8$ is outside the appropriate range of tannery waste and trimmings in the mixtures to be biodegraded, these $\mathrm{pH}$ values were closer to the anaerobic digestion (AD) range, showing that it was not the $\mathrm{pH}$ of the residues that was the limiting factor.

Table 6 presents the main studies that have been carried out on industrial tannery waste for biogas production, as well as the values of the main parameters.

Kameswari et al. [74] used ozonation as an alternative to increase the chemical demand for soluble oxygen (SCOD) since sludge hydrolysis requires a longer retention time. Cellular solubilization and hydrolysis of the

Table 4 Biodiesel characteristics in different world regulations

\begin{tabular}{|c|c|c|c|c|c|}
\hline \multirow[t]{2}{*}{ Feature } & \multirow[t]{2}{*}{ Units } & \multirow[t]{2}{*}{ Limits } & \multicolumn{3}{|l|}{ Method } \\
\hline & & & ABNT NBR & ASTM & EN/ISO \\
\hline$\overline{\text { Acidity }}$ & $\mathrm{mg} \mathrm{KOH/g}$ & 0.50 & 14,448 & 664 & EN 14104 \\
\hline \multirow[t]{2}{*}{ Water } & $\%$ & 0.05 & - & D 2709 & - \\
\hline & $\mathrm{mg} / \mathrm{kg}$ & 500 & a & D 6304 & EN ISO 12937 \\
\hline \multirow[t]{2}{*}{ Density } & $\mathrm{kg} / \mathrm{m}^{3}$ & $850-900$ & 7148 & 1298 & - \\
\hline & & $860-900$ & - & - & EN ISO 12185 \\
\hline \multirow[t]{3}{*}{ Viscosity } & $\mathrm{mm}^{2} / \mathrm{s}$ & $3.0-6.0$ & 10,441 & - & - \\
\hline & & $1.9-6.0$ & - & D 445 & - \\
\hline & & $3.5-5.0$ & - & - & EN ISO 3104 \\
\hline \multirow[t]{2}{*}{ Flash Point } & ${ }^{\circ} \mathrm{C}$ & $\min .100$ & 14,598 & - & EN ISO 3679 \\
\hline & & $\min .130$ & - & D 93 & - \\
\hline Mist Point & ${ }^{\circ} \mathrm{C}$ & b & 14,747 & D 2500 & EN ISO 3015 \\
\hline \multirow[t]{2}{*}{ Cetane Number } & $\mathrm{CN}$ & $\min .47$ & c & D 613 & - \\
\hline & & $\min .51$ & c & - & EN ISO 5165 \\
\hline
\end{tabular}

Source: Adapted from ANP [58]; ASTM D 6751 [59]; EN 14214 [60]

arazil uses the ASTM D 6304 [61] standard

${ }^{b}$ Value established in each country according to the prevailing climate

In Brazil, there is no minimum regulated value, being requested to register the measured value 
Table 5 Pretreatments to increase biogas production

\begin{tabular}{|c|c|c|c|}
\hline Pretreatment & & Observed Result & References \\
\hline \multirow[t]{2}{*}{ Thermal } & $121^{\circ} \mathrm{C}$ & Biogas production increase & [72] \\
\hline & $150^{\circ} \mathrm{C}$ & Biogas production increase & [73] \\
\hline Ozonation & $0.18 \mathrm{~g} \mathrm{O}_{3} / \mathrm{g} \mathrm{TS}$ & Biogas production increase & [74] \\
\hline Ultrasonication & $30 \mathrm{~s}$ & & \\
\hline Hydrodynamic cavitation & $5 \mathrm{bar} / 120 \mathrm{~min}$ & Biogas production increase & [22] \\
\hline Enzymatic (lipase) & $0.75 \mathrm{~g}$ & Increase in biogas production but it was not as high, so the enzyme acted as a catalyst & [74] \\
\hline Enzimatic (S. cerevisiae) & $1 \mathrm{~g}$ & Improves digestion by increasing biogas production & [70] \\
\hline Chemical $\left(\mathrm{K}_{2} \mathrm{HPO}_{4}\right)$ & $22.94 \mathrm{~g}$ & Biogas production increase & [18] \\
\hline
\end{tabular}

TS Total Solids

sludge performed with ozone breaks down the cell wall and releases SCOD, thus increasing biogas production. $0.18 \mathrm{~g}$ of $\mathrm{O}_{3} / \mathrm{g}$ TS was used, and this increased the biogas production to $310 \mathrm{~mL} / \mathrm{g}$. In another work by Kameswari et al. [77] used pre-treatment with enzymes, but the enzymes worked only as a catalyst, since the biogas production did not change much from $379 \mathrm{~mL} / \mathrm{g}$ to 389 $\mathrm{mL} / \mathrm{g}$. As the enzymatic treatment is expensive, there would be no other reason for its active use.

Researchers have studied the AD of solid waste from tanneries that contained chromium. The thermophilic AD of leather shavings and wastewater sludge was investigated [78]. The $\mathrm{pH}$ in the $\mathrm{AD}$ process initiates the acid and neutralizes throughout the process, in both sludge and shavings, $\mathrm{pH}$ tests started on average at 7.6 and increased to 8.2 [79]. According to Agustini [72], high VS values prove the high organic load of bovine leather waste, which makes them suitable for AD.

The predominant method of leather tanning is based on chromium salts, specifically trivalent chromium salts, which are the most used chemicals in tanneries. About $60-80 \%$ of the total amount of chromium applied during the tanning process is consumed, the rest of the chromium remains in the tanning float and subsequently remains as wastewater. Wastewater is treated by physicalchemical sedimentation before it can enter the biological

Table 6 Main parameter analyzed to obtain biogas

\begin{tabular}{|c|c|c|c|c|c|c|c|}
\hline \multirow[t]{2}{*}{ Feedstock } & \multicolumn{6}{|l|}{ Parameters } & \multirow[t]{2}{*}{ References } \\
\hline & $\begin{array}{l}\text { Biogas Generation } \\
(\mathrm{mL} / \mathrm{g})\end{array}$ & $\mathrm{pH}$ & $\begin{array}{l}\text { TS }(\mathrm{mg} / \mathrm{g})^{a} \text { or } \\
(\mathrm{mg} / \mathrm{L})^{\mathrm{b}}\end{array}$ & $\begin{array}{l}\text { VS }(\mathrm{mg} / \mathrm{g})^{\mathrm{a}} \text { or } \\
(\mathrm{mg} / \mathrm{L})^{\mathrm{b}}\end{array}$ & $\begin{array}{l}\mathrm{COD}(\mathrm{mg} / \mathrm{g})^{\mathrm{a}} \text { or } \\
(\mathrm{mg} / \mathrm{L})^{\mathrm{b}}\end{array}$ & $\begin{array}{l}\text { TKN (mg/g) or } \\
(\mathrm{mg} / \mathrm{L})^{\mathrm{b}}\end{array}$ & \\
\hline Sludge & 19.3 & 7.8 & - & $9810^{b}$ & - & - & [18] \\
\hline $\begin{array}{l}\text { Raw tannery waste } \\
\text { effluent }\end{array}$ & 68.57 & 7.5 & $18850^{b}$ & $4650^{b}$ & - & - & [22] \\
\hline Leather fleshings & 460.0 & 12.5 & $2240^{b}$ & $1670^{b}$ & $221^{a}$ & $14^{\mathrm{a}}$ & [23] \\
\hline Treatment sludge & & 7.9 & $2240^{\mathrm{b}}$ & $1490^{b}$ & $252^{\mathrm{a}}$ & $11.1^{\mathrm{a}}$ & \\
\hline Shavings & 19.3 & 4.03 & - & $9400^{b}$ & - & - & [72] \\
\hline Primary sludge & 385.0 & 8.1 & $35000^{b}$ & $18900^{b}$ & $24950^{b}$ & $29^{\mathrm{a}}$ & [68] \\
\hline Second sludge & & 7.3 & $15220^{b}$ & $7610^{b}$ & $9890^{b}$ & $42^{a}$ & \\
\hline Fleshings & 470.0 & 11.67 & $150^{a}$ & $730^{\mathrm{a}}$ & $990^{a}$ & $116^{\mathrm{a}}$ & [76] \\
\hline Primary sludge & & 8.4 & $68030^{b}$ & $35660^{b}$ & $46490^{b}$ & $42^{b}$ & \\
\hline Second sludge & & 7.5 & $27650^{b}$ & $15180^{b}$ & $19940^{b}$ & $46^{\mathrm{b}}$ & \\
\hline Fleshings & - & 11.1 & $100^{\mathrm{a}}$ & $650^{\mathrm{a}}$ & $900^{a}$ & $76^{\mathrm{a}}$ & [77] \\
\hline Fleshings & 310.0 & - & $17.5^{\mathrm{a}}$ & $14^{\mathrm{b}}$ & - & - & [74] \\
\hline Primary sludge & & 8.4 & $96300^{b}$ & $3780^{b}$ & - & - & \\
\hline Second sludge & & 7.6 & $46800^{b}$ & $19950^{b}$ & - & - & \\
\hline Leather fleshings & 20.22 & - & 5452 & 5055 & - & - & [73] \\
\hline Hide powder & & - & 8324 & 8262 & - & - & \\
\hline Primary sludge & & - & 184 & 104 & - & - & \\
\hline Second sludge & & - & 239 & 133 & - & - & \\
\hline
\end{tabular}

a and ${ }^{b}$ Refers to the different units in which the analyzes were performed

TS Total solid, VS Volatile solid, COD Chemical oxygen demand, TKN Total Kjeldahl Nitrogen 
treatment process, where flocculated/sedimented pollutants are discarded as sludge. Direct landfilling of tanning sludge is not allowed, as it is considered dangerous due to the high content of organic and trivalent chromium. With this, anaerobic digestion emerges as an alternative for the recycling this waste containing chromium (III) to produce biogas [18].

Golub et al. [80] studied the effect of some compounds on biogas production. The tannery wastewater treatment sludge contains $\mathrm{NaCl}, \mathrm{NaCO}_{3}$, antiseptics, and antibiotics, these compounds are inhibitors in the fermentation process to produce methane. The addition of $\mathrm{NaCO}_{3}$ confers reduction in methane production from 220 to $38 \mathrm{~cm}^{3} / \mathrm{g}$. With the presence of $\mathrm{NaCl}$, the production of methane was $594 \mathrm{~cm}^{3} / \mathrm{g}$ and in the absence of this, the production was $113 \mathrm{~cm}^{3} / \mathrm{g}$. And for antibiotics, in high concentrations of tetracycline and norfloxacin, there was a great decrease in the production of biogas, 25 and $100 \mathrm{~cm}^{3} / \mathrm{g}$, respectively, as it inhibits the association of microorganisms at the beginning of fermentation.

The main challenges to produce biogas from chromium-tanned leather are the efficiency of production compared to other types of waste because chromium (III) removes a part of the organic load from the leather and this organic part improves anaerobic digestion. Also, the presence of other compounds (salts, antiseptics, and antibiotics) in tannery sludge also proved to be potential inhibitors in the production of biogas.

\subsection{Biopolymers}

Pollution caused by polymers of petroleum origin is an important environmental challenge today, as around 300 million tons are produced annually worldwide, and approximately 8 million ends up in the oceans each year, with a tendency to double this amount by 2034 [81]. The degradation time of the material is a factor of great relevance, which causes the transfer of organic pollutants to humans and biota [82]. Therefore, understanding and managing this pollution is a priority for companies, and scientists [83].

In this context, transforming industrial waste into useful material promotes economic flow. A sustainable alternative that can be adopted in the case of pollution originating from fossil polymers, is the extraction of collagen and/or gelatin present in residues from the leather processing industry for application as biodegradable films [24].

The advantage of biodegradable films lies in the more accelerated degradation kinetics, directly associated with solubility and microbial action since the solubilization makes the film components available to the microbiota present in the soil, which includes bacteria, fungi, and protozoa [84]. The biodegradability of the films allows them to be used as fertilizers [85].

Masilamani et al. [26] studied the extraction of gelatin from raw bovine skin from tannery wastes, through acid hydrolysis, which was subsequently dried and ground to be used in the production of films. During the study, the authors made optimizations in the formulation of the film, incorporating a polymer composed of polyvinyl alcohol (PVA), glycerol and glutaraldehyde to obtain a performance similar to the low-density polyethylene (LDPE) film, used as a control. Mechanical, thermal sealability and printing tests have shown good results for packaging applications. In the printing test, the samples were scribed and stamped with different inks, and the standardized film samples were placed in the water for $1 \mathrm{~h}$. The optimized film in this study, which used extracted gelatin, glycerol, PVA and glutaraldehyde, performed better than the control composed of LDPE.

Muralidharan et al. [24] performed the extraction of the hydrolysate of raw skin chips through hydrothermal hydrolysis. The material obtained was lyophilized and the films were made by mixing the powder with PVA and citric acid. Citric acid showed antimicrobial properties, which suggest the applicability of films in the packaging and wound healing, in addition to acting as a plasticizer, resulting in improvements in the mechanical properties, transparency, and uniformity of films comparable to conventional polymers.

Sartore et al. [25] used collagen hydrolysate from chromium-free leather industry residues, polyethylene glycol (PEG) and epoxidized soybean oil to make biodegradable spray coatings and apply to the soil for later lettuce planting. The authors concluded that the material produced had an agronomic performance comparable to that of a commercial low-density polyethylene film, maintaining the covering effect during the growing period, in addition to guaranteeing a similar rate of plant growth and accumulation of dry matter. At the end of the field test, the soil covered with the polyethylene film registered a lower electrical conductivity value compared to the soil covered with the sprayed coatings, this can be attributed to the nutrients released into the soil by the spray during its decomposition.

Scopel et al. [86] compared films made with gelatin extracted from tannery wastes tanned to chromium (III) and films made with commercial gelatin, adding corn starch and glycerol. The authors concluded that the extracted gelatin makes the starch films more hygroscopic, more soluble in water, less resistant and more flexible. Therefore, to use gelatin and/or hydrolysate extracted from RCCC, some disadvantages for filmmaking, such as low mechanical properties, high degradation rate, and high hydrophilic capacity need to be overcome. The challenge is to propose the use of compounds and / or 
additives that can promote improvements in the polymer matrix to obtain materials with properties equivalent to products obtained from petroleum [26].

In the study by Rosseto et al. [87] the possibilities of applying gelatin extracted from chromium-tanned leather waste are discussed, with properties enhanced by enzymatic and antimicrobial treatment. The use of these films in agriculture is interesting, as their applications in the food industry are not viable due to the residual chromium attached to the protein molecules. Among the application options, the authors point out the use of land cover as promising (Fig. 4).

Dang et al. [88] added $\beta$-cyclodextrin to the gelatin of chromium-tanned leather residues for filmmaking and concluded that it can form intermolecular bonds with gelatin, improving its properties and increasing the applicability of mixtures, for example, in the scientific fields, medical and commercial. Erciyes and Ocak [89] used hydrolyzed collagen from chromium-tanned leather residue to make films with the addition of titanium dioxide. The results revealed that the incorporation of titanium dioxide decreased the permeability to water vapor, the solubility in water and the elongation at break of the films, while increasing the tensile strength, indicating that the film can be a promising alternative material in the industry non-food packaging. Ocak [90] used hydrolyzed collagen from chromium-tanned leather waste to make films, with the addition of chitosan. The addition of chitosan caused an increase in the properties of tensile strength, elongation, and thickness, in addition to decreasing water solubility, presenting good homogeneity in the film structure.

Gil et al. [91] studied the removal of chromium from hydrolyzed collagen for the preparation of films with the addition of antibiotics (silver sulfadiazine), aiming to apply them as a curative covering of wounds (wounds and burns) to aid in healing, by eliminating the dressing change. The release of the antibiotic on the skin would occur slowly during treatment. The tests were performed with Wistar rats (6 to 8 weeks, 220 to $250 \mathrm{~g}$ ). The results were promising, demonstrating that the material can administer the drug, releasing it in a controlled manner, in addition to having great efficiency in inhibiting bacteria, and cellular compatibility, thus creating a new field of study from a material that presents a serious environmental liability.

Dang et al. [92] produced a biodegradable liquid film with oxidized modified corn starch and gelatin extracted from tannery wastes, through alkaline hydrolysis, the chromium present in the gelatin was removed following the steps of removing organic matter, oxidation, chromium (VI) extraction, which was deoxidized and underwent basic adjustment. The authors applied the films to the rapeseed plantation, where they showed good water absorption and retention properties, increasing the germination rate of the rapeseed seeds.

As discussed in this topic, it is clear that tannery wastes are promising for applications in the production of biodegradable films, however, more research is needed in the development of composites with appropriate combinations of compounds and/or additives that can promote changes and improvements in the polymer matrix to enable its effective application.

\subsection{Agriculture}

The productivity of a crop is related to the availability of nutrients in the soil during its development. To meet the needs of the plant, fertilizers must be applied to the soil to ensure all the macros and micronutrients essential to its growth process [93].

Tannery wastes have been widely used as fertilizers to improve agricultural production, due to the amount of nitrogen and organic matter available [94]. Studies suggest different ways to apply this waste, according to the scheme in Fig. 5.

Nabavinia et al. [32] evaluated the mixture of hair removal residues and biochar as to their effects on the growth and production of radishes. It was observed that the fertilizer increased the content of nitrogen and phosphorus in the soil, leading to an increase in the fresh and dry mass of the vegetable. The application of these is useful due to the high content of nutrients, mainly in
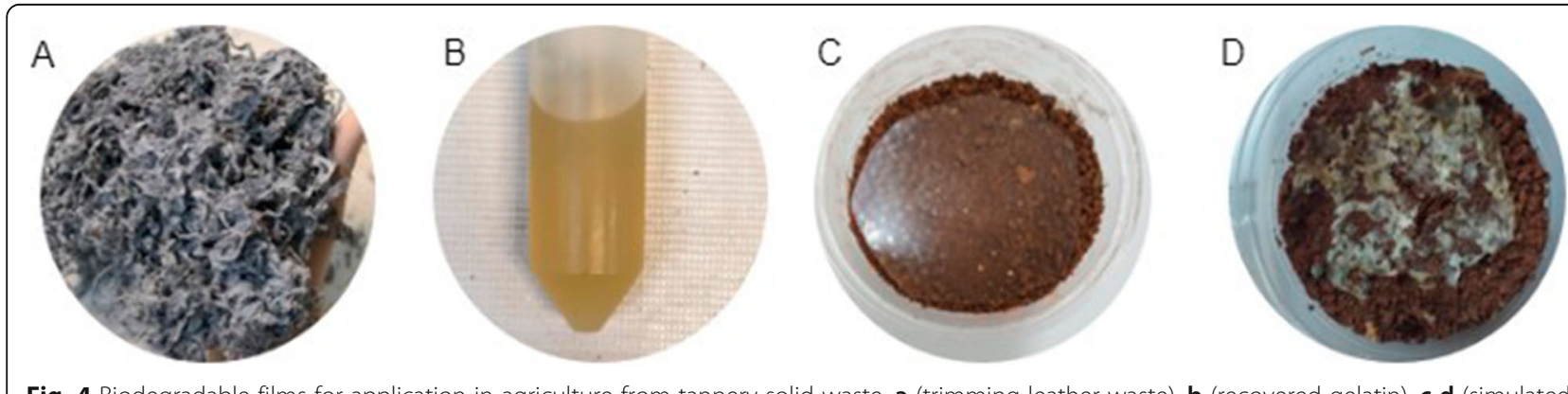

Fig. 4 Biodegradable films for application in agriculture from tannery solid waste, a (trimming leather waste), b (recovered gelatin), c-d (simulated soil application test: time 0 and 60 days, respectively) 


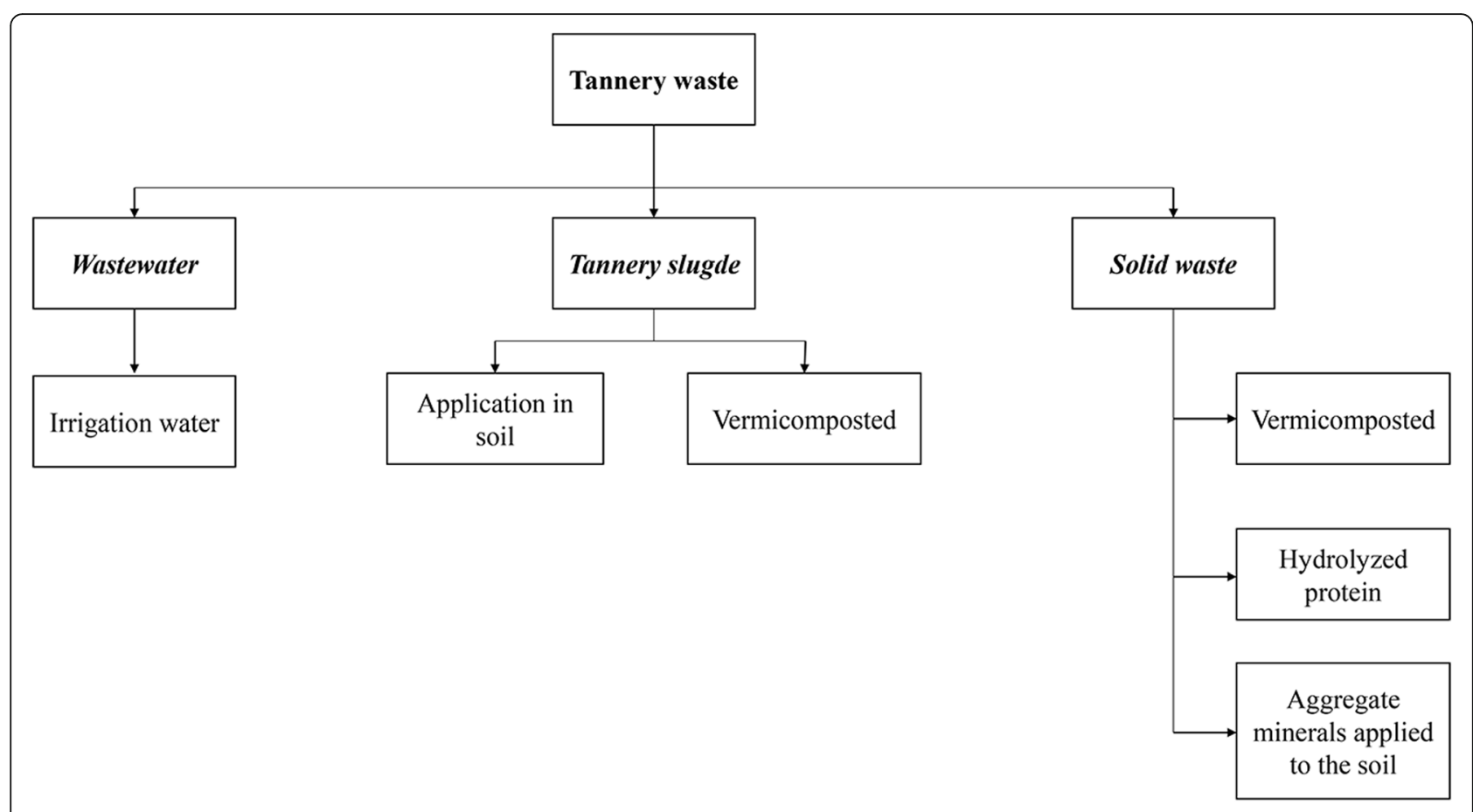

Fig. 5 Origin and destination of tannery wastes for application in agriculture

regions of soils with carbon deficiency (arid and semiarid soils), increasing the yield of plants.

The use of bacteria to transform the waste of goat leather (complex protein molecules) into simple soluble molecules has also been studied. With the aid of bacteria of the species Selenomonas ruminantium, tannery waste was fermented in a submerged state (treatment 1) and a solid-state (treatment 2). Two other treatments with mineral fertilizer and control were carried out. The fermented hydrolysates obtained better results. The solid-state hydrolysate had a greater influence on the growth of tomatoes, stem diameter and quantity of leaves due to the higher nitrogen concentration offered for the plants [95].

Silva et al. [96] applied sludge from a tannery wastewater treatment plant to cultivate Capsicum sp., An ornamental plant. Two treatments were carried out, T1 (tannery sludge, cow dung and cane straw), T2 (tannery sludge, cow dung and carnauba straw). It was found that for both treatments the plant had a greater number of leaves and fruits. The chlorophyll content was higher in the $\mathrm{T} 1$ treatment, showing that a high nutrient content is proportional to the increase in pigment present in the species.

Malafaia et al. [31] used tannery sludge produced during skin hair removal step in the corn crop, although there was an increase in the concentrations of phosphorus, potassium, magnesium and calcium (which impacts on the increase in soil fertility) there was no increase in the yield of the corn crop when compared to mineral fertilization.

Vermicomposting has been a technique used to improve the biochemical properties of the fertilizer obtained from tannery waste. The technique is summarized in the addition of earthworms, which have in their intestine's mesophilic microorganisms capable of bioxidizing and stabilizing organic matter, transforming it into a substance rich in nutrients. The material excreted by earthworms is known as vermicompost [30]. Figure 6 shows a scheme of vermicomposting with tannery waste.

Ravindran et al. [97] added cow dung and sawdust to goat leather waste to produce fertilizer. The residue was decalcified and fermented in a solid and submerged state, to later receive earthworms for vermicomposting. A treatment without the use of earthworms was also carried out with the same materials. The results demonstrated that vermicompost treatments can generate greater availability of nutrients, such as indole 3 -acetic acid, kinetin, and gibberellic acid, which are essential for plant growth.

Another study about vermicompost tanned leather shavings, mixed with cow dung and sawdust was carried out by Nunes et al. [98] to produce organic sweet peppers. The authors compared this fertilizer with a control treatment (soil use only) and another treatment with mineral fertilizer (NPK). It was observed that the vermicomposted fertilizer had a positive influence on plant growth and produced more fruits per plant when 


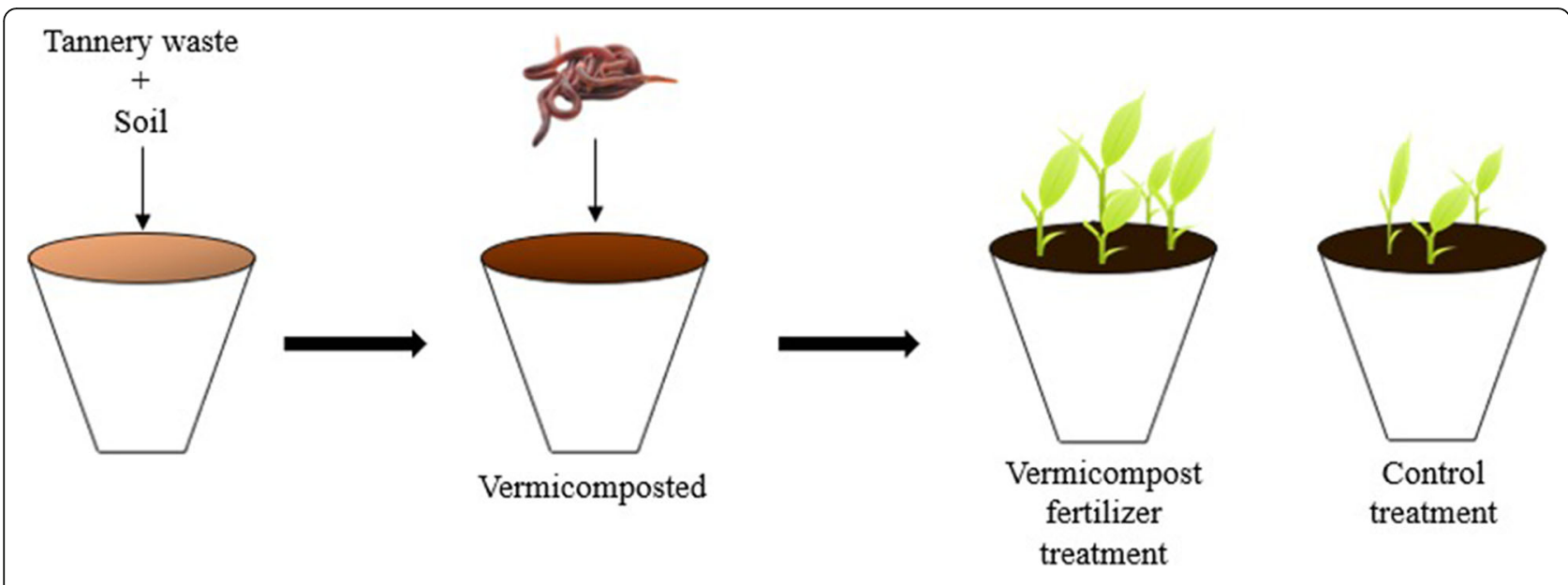

Fig. 6 Stages of vermicompost production from tannery waste

compared to mineral fertilizer in a 3:1 ratio. Chromium was detected in the fruits in levels that varied from 145.06 to $165.20 \mu \mathrm{g} / \mathrm{kg}$, these concentrations are not enough to induce any danger to human health [99].

Ravindran et al. [100] evaluated the potential of tannery hair removal wastes to vermicomposted to produce tomatoes. The authors used the hydrolyzed wastes in a solid and submerged state, in the form of compound and vermicompost. The product was applied to the soil and the growth, production and chemical composition of tomatoes were evaluated. It was observed that the hydrolyzed wastes in solid-state, both for composting and for vermicomposting, obtained better results when compared with the hydrolysate in submerged state. The treatments with vermicompost showed an increase of $10 \%$ in the height of the plant, $8.9 \%$ in the diameter of the plant's stem and $14 \%$ in the number of leaves.

A fertilizer based on chromium-tanned leather waste, added with phosphorus $(\mathrm{P})$ and potassium $(\mathrm{K})$ was studied by Nogueira et al. [101]. The authors extracted the chromium contained in the waste through acid hydrolysis at a temperature of $50^{\circ} \mathrm{C}$. The hydrolyzed residue was immersed in solutions of $\mathrm{P}$ and $\mathrm{K}$, dried and ground in different particle sizes. Treatments were performed with commercial fertilizer and obtained from residue to evaluate the growth of rice plants. The formulations with residue produced less dry mass, but increased the grain yield in plants, showing itself as a source of nutrients for the crop.

Fertilizer encapsulation has also been shown to be a promising technique for use in agriculture. Its advantage over conventional application is the slow release of the nutrient contained within the capsules as required by the plant, which helps in the efficiency of mineral absorption by the plant and prevents the material from leaching into the soil $[93,102]$. Encapsulation occurs with the formation of a film/membrane on the active agent - mineral salts or fertilizer. The coating occurs with the use of polymers such as chitosan, starch, gelatin, among others [103]. The capsule can be obtained by dripping a liquid solution in water or oil, as well as spraying the coating polymer over fertilizer grains. The release the fertilizer occurs with the entry of water through the polymer wall causing a difference in osmotic pressure between the inside of the capsule and the outside, which will end up releasing the contents to the environment.

The use of gelatin extracted from chromium-tanned leather waste was used as an encapsulating agent by Dang et al. [104]. The material was sprayed on fertilizer granules and tested in the bean culture for growth evaluation. It was seen that the height and germination rate increased when compared to the control treatment. In this experiment, starch was added to reduce the solubility of gelatin when exposed to the environment, since it has hydrophilic characteristics. It was noticed that in treatments with higher gelatin composition, the productivity of beans was higher.

Although tannery wastes are promising for applications such as fertilizers, there are still some questions about their use. Ali et al. [105] found that the application of wastewater from the tannery effluent treatment plant limited the growth and development of wheat biomass. Such an effect can be associated with the accumulation of metals in the soil, such as chromium, promoting stress in plants and reducing the action of antioxidant molecules [94].

It is important to point out to the reader that the negative effects of chromium on the development of plants and even its oxidation in $\mathrm{Cr}^{6}+$ depends on the mobility and availability of other organic and inorganic compounds also present in the residue or the soil. Specific conditions are necessary for the metal in question to cause damage to flora, microbial fauna, and even 
human health [94]. Also, some substances can be added to reduce the toxic effect of chromium such as fulvic acid $[105,106]$.

\subsection{Other applications}

Besides the possibilities presented above, solid wastes from the tannery industry have also been widely studied to obtain added-value products, extraction of compounds of industrial interest, isolation of microorganisms and production of enzymes, in addition to applications focused on animal diet.

\subsubsection{Extraction/recovery of compounds of industrial and/or commercial interest}

The extraction of elastin, a protein-based material that serves as an ingredient for jellies, moisturizers, antiaging, and personal care products has been studied from untanned leather waste. Yoseph et al. [107] achieved a 90\% yield for elastin extraction from raw hide trimming wastes by the thermochemical treatment method using alkaline pre-treatments. The biocompatibility analysis using human keratinocyte cells confirmed the presence of a non-toxic nature of the extracted elastin, favoring its application in dermatological products, for example.

Collagen is also an abundant component in tannery solid wastes, where its fibrous characteristic can be valued for applications such as acoustic blocking because it provides a multitude of small openings through which sound energy is dissipated by viscous and thermal losses [108]. Selvaraj et al. [109] performed the recovery of collagen hydrolysate from fleshing wastes through acid hydrolysis to form nanofibres for application as a layer of a natural coconut fiber sound-absorbing material. The nanofiber membrane optimized sound absorption at lower frequencies $(100-1000 \mathrm{~Hz})$ when compared to coconut fiber only. Other works were also successful in recovering collagen from leather industry waste through different methods, such as dissolution in 1-allyl-3methylimidazolium chloride [110], dissolution in different salts [111], solubilization in propionic acid and acetic acid [112] and through dechroming by hydrolysis, using the conventional bating enzyme [113].

Obtained from the chemical and thermal degradation of collagen, gelatin is also a component of industrial interest because it is a polymer with high biological compatibility [114] and multifunctional properties, improving the elasticity, consistency, and stability of a variety of products [115]. However, gelatin from trivalent chromium-tanned leather residues cannot be applied in food package because the presence of chromium [116].

Catalina et al. [115] obtained a $96 \%$ reduction in the chromium content of the gelatin extracted from chromium-tanned shavings, through the oxidative decromification method, which consists in removing the chromium from the tannery solid wastes without affecting the properties of the original fibers [117]. In an attempt to optimize the extraction process of gelatin from trivalent chromium-tanned leather residues, Scopel et al. [118] employed the alkaline hydrolysis method with $\mathrm{CaO}$ and steam explosion, obtaining an extraction yield of $30 \%$, with a temperature of $140^{\circ} \mathrm{C}$ for $10 \mathrm{~min}$, the gelatin quality was considered satisfactory (viscosity of 2.4 $\mathrm{cP}$ at $25^{\circ} \mathrm{C}$ in a protein solution of $24.6 \mathrm{~g} / \mathrm{L}$, the molar mass of $39 \mathrm{kDa}$ ). The proposed process reduced the extraction time from 12 to 36 times compared to traditional extraction methods.

The ashes generated during the gasification and combustion process of tannery wastes are chromium-rich, containing between 50 and $60 \%$ chromium oxide $\left(\mathrm{Cr}_{2} \mathrm{O}_{3}\right)$ by mass, and were studied by Dettmer et al. [16] as a source of chromium for the synthesis of sodium chromate $\left(\mathrm{Na}_{2} \mathrm{CrO}_{4}\right)$ using sodium nitrate to oxidize $\mathrm{Cr}$ (III) to $\mathrm{Cr}(\mathrm{VI})$. The authors achieved a conversion of more than $94 \%$, and the sodium chromate obtained from ashes showed similar physical properties to the commercial product.

Kluska et al. [119] evaluated a mixture of pelletized leather tannery wastes with hardwood pellets as potential fuel for heat production. Their experimental results showed that tannery wastes can be a promising fuel, with a relatively high heating value, at the level of $16 \mathrm{MJ} /$ $\mathrm{kg}$ and volatile content of $68 \%$, and that hardwood pellets together with leather do not have a significant impact on the temperature characteristics of the combustion process. A similar study was conducted by Kluska et al. [120], who evaluated the formation of ashes in the combustion process of pelletized leather tannery waste and hardwood pellets. As a critical point of the process, it was observed that with the increase of the percentage of pelletized leather tannery waste in the mixture, the thickness of the ash layer that accumulates in the grate increases, due to the higher mineral content present in tannery solid waste.

Onukak et al. [121] evaluated the use of 6 types of biomass briquettes, comprising varying ratios of hair, flesh, chromium-tanned shavings, and buffing dust, as a possible fuel for energy production and, the results obtained were within the range of 17.4 to $24.1 \mathrm{MJ} / \mathrm{kg}$, comparable to other fuel sources, such as sub-bituminous coal (20, 000 to $24,730 \mathrm{MJ} / \mathrm{kg}$ ).

Aiming to develop a technique that can reduce the pollution of buffing dust in the air resulting from the leather finishing stages, Hashem and Nur-A-Tomal [122] manufactured a composite from condensed buffing dust and compared its physical properties with the standard of suitability used in the leather products industry. The tensile strength and elongation to rupture ratio of the material are shown to be adequate using 
adjustments of $50 \%$ in the latex dosage, $5 \%$ of aluminum sulfate and $\mathrm{pH}=5$. The authors concluded that the composite developed is suitable for the manufacture of insoles.

The incorporation of tannery solid wastes in composite production was also studied by Ruiz et al. [123] who developed a composite based on vulcanized natural rubber, carbon black and buffing, stripping, and shaving wastes, processed by thermal compression with $60 \mathrm{phr}$ of natural rubber and 60 or 80 phr of tannery waste, making possible application as an antistatic coating. Following the Brazilian sanitary laws, the material was exposed for $24 \mathrm{~h}$ in bleach and to a disinfectant to simulate a real daily cleaning use. The structural and morphological characteristics showed no significant changes after exposure and, with the addition of tannery waste, the electrical conductivity increased from $5.70 \times 10^{-6}$ to $7.97 \times 10^{-4} \mathrm{~S} / \mathrm{cm}$. The results obtained indicated a possibility of applying the composite as an antistatic coating as it exhibits acceptable values of electrical conductivity and is structurally, morphologically, and electrically resistant to exposure to disinfectant agents.

Other studies also aimed at the production of materials of commercial value using solid leather waste from various stages of the process, these materials being cement [124-126], lactic polyacid composites [127], activated carbon to replace carbon black in tire production [128], dry resistance additive for papermaking [129] and ceramic pigment [130].

\subsubsection{Isolation of enzymes and microorganisms}

Recently, enzyme and fermentation-based techniques have also been explored for the management of tannery residues. Enzymatic degradation assisted by microorganisms is considered a sustainable process, as it decomposes complex compounds into smaller intermediates without significant environmental impact [131]. Proteases are responsible for $60 \%$ of total enzyme sales in the world market and are used in several sectors, including food, leather, dairy, pharmaceuticals, and waste management [132, 133]. Ravindran et al. [134] and Kumar et al. [135] evaluated the protease production using animal fleshing as substrate, through the bacteria Clostridium limosum and Synergistes sp., respectively.

Enzymes can also be applied to decrease the environmental impact on the leather production process itself, Dettmer et al. [14] performed the isolation of a new protease from Bacillus subtilis, filtered from aerobic tanning sludge. The authors' goal was to replace the depilation step with an enzymatic process. The crude enzymatic extract obtained showed the best proteolytic activities at pH 9 and 10 , temperature between 37 and $55^{\circ} \mathrm{C}$, and showed good thermal stability up to $45^{\circ} \mathrm{C}$. The hides treated with the enzymatic extract showed few hairs and the removal of interfibrillar proteins was approximately four and six times higher, for proteoglycan glycosaminoglycans, respectively, when compared with the conventional process. The application of the enzyme was successful in the treatment of hides, suggesting that this enzymatic preparation can be used in an ecological leather production to replace the conventional chemical process.

Puhazhselvan et al. [136] used Bacillus subtilis MTCC 6537 protease to extract lipids from tannery fleshing waste and obtained higher yields of 23.12, 36.5 and $43.18 \%$ of lipids, compared to thermal hydrolysis, Soxhlet Bligh \& Dyer extraction methods, respectively. Fungal lipases were also produced from beef fleshing of tannery solid waste as a substrate $[137,138]$.

However, the isolation of microorganisms from tannery industry wastes was also studied, such as Trichosporon loubieri RC-S6 [139], Bacillus sp. strain FH5 [140] and Bacillus firmus TAP5 [141].

\subsubsection{Animal diet}

Some authors have studied the influence of vegetabletanned wastes on the diet of broilers [142] and cattle [143]. In both studies three distinct diets were tested: D1 (containing 10\% commercial protein concentrate), D2 (containing 5\% commercial protein concentrate $+5 \%$ tannery waste) and D3 (containing 10\% tannery waste). For broilers, the authors concluded that diets did not affect meat production characteristics, however, gizzard and ham weights were improved with the increased level of tannery residues in the diet. For bovines, D2 and D3 diets showed a significant effect $(p<0.05)$ on weight gain and profitability when compared to the control diet (D1). Specifically, body weight gain was a result of the high level of protein and availability of essential amino acids available in leather waste compared to commercial protein concentrate. Bovines fed with tannery wastes showed no changes in the normal characteristics of the carcass and the chemical composition of the muscles.

Chaudhary and Pati [144] have performed the hydrolysis and purification of protein derived from chromiumtanned wastes to be used as a partial substitute for soybean meal for broiler chickens. Two dosages (with 20 and $30 \%$ purified protein hydrolysate in soybean meal) were evaluated. The diet showed significant effects on feed intake and body weight gain. Birds fed 20 and 30\% protein hydrolysate consumed 9.5 and $17.5 \%$ more feed and gained 6.5 and $16.6 \%$ more weight than soybean meal alone, respectively. Protein hydrolysate proved to be economically profitable and could replace up to $75 \%$ of soybean meal in broiler diets without affecting growth performance and meat characteristics.

Certainly, one of the biggest challenges that guide the use of tannery wastes for animal diet applications, is 
related to its toxicity in the animals' organism. In this sense, Jini et al. [145] evaluated the acute and subacute toxicity in rats that were fed diets containing delimed tannery fleshing (DTF) and hydrolysates obtained by acid $(\mathrm{AH})$ and fermentation $(\mathrm{FH})$ hydrolysis. It was found that both hydrolysates (AH or FH) and DTF can be supplemented in diets, mainly birds and fish, of up to $15 \%$ without inducing toxicity-related changes, as evidenced by analyses of body weight gain, feed efficiency, organ weight, hematology, histology, and serum biochemistry. The authors also emphasize the importance of the continuity of studies to establish the complete nutritional safety of animal feed based on tannery waste and/or hydrolysates, expanding the possibilities of use of these residues in a sustainable and environmentally correct way.

As is noticed along with this work, there are a lot of possibilities to reuse and recycling tannery wastes. Making a fast analysis among the alternatives presented before, it is possible to say that the uses which no pre or treatment needs to be are the more attractive ones. The shavings used as adsorbent are a good example, as presented in Table 1 it is possible to remove more than $85 \%$ from an initial dye's concentration using chromium-tanned leather. In this same way, we can cite the sludge from hair removal that is used for agricultural purposes, both can be used without any kind of treatment and so without costs with chemicals and other processes. Moreover, the application of products obtaining from tannery wastes in the medical or food field, there are several parameters to be reached before finding the appropriate purification. Unlike other materials approached, such as cement, paper, and rubber, which have a more direct application, without major concerns about their toxicity.

\section{Conclusions and perspectives}

This review addressed the main methods recently studied for the use of tannery waste for the areas of adsorption, biodiesel, biogas, biopolymers, applications in agriculture, hides process and animal diets. Many promising results were evidenced, however, there are still challenges that need to be overcome to make it possible to obtain products of commercial value and/or to extract/recover compounds of industrial/commercial interest. The challenges faced by each technique were also mentioned in the respective topics.

Regarding the perspectives, it is emphasized that these products obtained from leather wastes for applications in the mentioned areas, would guarantee greater profitability for the leather processing industries, in addition to the development of new economic models exclusively for the processing of wastes. We believe that a greater focus on researches on the sustainable management of solid tannery wastes will enable improvements and advances to be achieved in the various application areas addressed, contributing directly to scientific development and environmental preservation.

\section{Acknowledgments \\ The authors would like to acknowledge the Coordination for the Improvement of Higher Education Personnel (CAPES) - Finance Code 001, the National Council for Scientific and Technological Development (CNPq) - Proc. 409173/2018-5, Research Support Foundation of Rio Grande do Sul (FAPERGS) - Proc. 16/0258-4 and University of Passo Fundo (UPF) for their financial support in this research.}

\section{Authors' contributions}

CVT R - Project administration, Methodology, Writing-Original draft preparation and Data curation; M R - Writing-Original draft preparation; DDC K Writing-Original draft preparation; BEP O - Writing-Original draft preparation; LA M - Writing-Original draft preparation; BB Z - Writing-Original draft preparation; A D - Visualization, Supervision, and Editing. The author(s) read and approved the final manuscript.

\section{Funding}

Not applicable.

Availability of data and materials

Not applicable.

\section{Competing interests}

Not applicable.

\section{Author details}

${ }^{1}$ Postgraduate Program in Food Science and Technology (PPGCTA), University of Passo Fundo (UPF), Faculty of Agronomy and Veterinary Medicine (FAMV), Passo Fundo, RS, Brazil. ' ${ }^{2}$ Chemical Engineering Course, University of Passo Fundo (UPF), Faculty of Engineering and Architecture (FEAR), Passo Fundo, RS, Brazil.

Received: 28 April 2020 Accepted: 8 July 2020

Published online: 12 August 2020

\section{References}

1. EPA - United States Environmental Protection Agency. What are the trends in wastes and their effects on human health and the environment? 2018. https://www.epa.gov/report-environment/wastes. Accessed 20 Mar 2020.

2. USDA - United States Department of Agriculture. Brazil once again becomes the world's largest beef exporter. 2019. https://www.ers.usda.gov/ amber-waves/2019/july/brazil-once-again-becomes-the-world-s-largest-beefexporter/ Accessed 3 Mar 2020.

3. CICB - Brazilian Leather Industries Center. Sector data. 2020. http://www. cicb.org.br/cicb/dados-do-setor. Accessed 5 Mar 2020.

4. Amalraj A, Pius A. Removal of selected basic dyes using activated carbon from tannery wastes. Sep Sci Technol. 2014. https://doi.org/10.1080/ 01496395.2013.819018

5. Yılmaz O, Kantarli IC, Yuksel M, Saglam M, Yanik J. Conversion of leather wastes to useful products. Resour Conserv Recycl. 2007. https://doi.org/10. 1016/j.resconrec.2006.05.006.

6. ABNT NBR 10004. Solid waste - classification. 2004. http://www.suape.pe. gov.br/images/publicacoes/normas/ABNT_NBR_n_10004_2004.pdf. Accessed 27 Mar 2020

7. ABNT NBR 10005. Procedure for obtention leaching extract of solid wastes. 2004. https://wp.ufpel.edu.br/residuos/files/2014/04/ABNT-NBR-10005Lixiviacao-de-Residuos.pdf. Accessed 27 Mar 2020.

8. Alves VC, Barbosa AS. Management practices of leather footwear industry in Franca-SP. Gest Prod. 2013. https://doi.org/10.1590/S0104530X2013005000006.

9. Rio Grande do Sul. Rio Grande do Sul state solid waste plan: PERS/RS 20152034. 2015. https://www.sema.rs.gov.br/upload/arquivos/201905/03155207pers-cartilha.pdf Accessed 6 Mar 2020. 
10. Kipper E. Enzymatic treatment and biogas production by tannery solid wastes: Dissertation, Federal University of Rio Grande do Sul; 2013. https:// lume.ufrgs.br/handle/10183/96507?locale-attribute=en\&show=full.

11. Gutterres M. Analysis of vegetable tannin absorption during the tannage of hide/hide powder. J Am Leather Chem Assoc. 2007;102:216-21.

12. Dettmer A, Ayub MA, Gutterres M. Hide unhairing and characterization of commercial enzymes used in leather manufacture. Braz J Chem Eng. 2011 https://doi.org/10.1590/S0104-66322011000300003.

13. Dettmer A, Cavalheiro JC, Cavalli E, Rossi DM, Gusatti CS, Ayub MAZ, Gutterres M. Optimization of the biotechnological process for hide unhairing in substitution of toxic sulfides. Chem Eng Technol. 2012. https:// doi.org/10.1002/ceat.201100350.

14. Dettmer A, Cavalli É, Ayub MA, Gutterres M. Optimization of the unhairing leather processing with enzymes and the evaluation of inter-fibrillary proteins removal: an environment-friendly alternative. Bioprocess Biosyst Eng. 2012. https://doi.org/10.1007/s00449-012-0719-z.

15. Dettmer A, Cavalli É, Ayub MA, Gutterres M. Environmentally friendly hide unhairing: enzymatic hide processing for the replacement of sodium sulfide and delimig. J Clean Prod. 2013. https://doi.org/10.1016/j.jclepro.2012.04.024.

16. Dettmer A, Nunes KGP, Gutterres M, Marcílio NR. Obtaining sodium chromate from ash produced by thermal treatment of leather wastes. Chem Eng J. 2010. https://doi.org/10.1016/j.cej.2010.02.018.

17. Dettmer A, Nunes KGP, Gutterres M, Marcílio NR. Production of basic chromium sulfate by using recovered chromium from ashes of thermally treated leather. J Hazard Mater. 2010. https://doi.org/10.1016/j.jhazmat.2009.11.090.

18. Booramurthy VK, Kasimani R, Subramanian D, Pandian S. Production of biodiese from tannery waste using a stable and recyclable nano-catalyst: an optimization and kinetic study. Fuel. 2020. https://doi.org/10.1016/j.fuel.2019.116373.

19. Booramuthy VK, Kasimani R, Pandian S. Biodiesel production from tannery waste using a nano catalyst (ferric-manganese doped sulphated zirconia). Energ Sources A. 2019. https://doi.org/10.1080/15567036.2019.1639849.

20. Šánek L, Pecha J, Kolomazník K, Bařinová M. Biodiesel production from tannery fleshings: feedstock pretreatment and process modeling. Fuel. 2015. https://doi.org/10.1016/j.fuel.2015.01.084.

21. Agustini CB, da Costa M, Gutterres M. Tannery wastewater as nutrient supply in production of biogas from solid tannery wastes mixed through anaerobic co-digestion. Process Saf Environ Prot. 2020. https://doi.org/10. 1016/j.psep.2019.11.037.

22. Saxena S, Saharan VK, George S. Modeling \& simulation studies on batch anaerobic digestion of hydrodynamically cavitated tannery waste effluent for higher biogas yield. Ultrason Sonochem. 2019;58:104692. https://doi.org/ 10.1016/j.ultsonch.2019.104692.

23. Bayrakdar A. Anaerobic co-digestion of tannery solid wastes: a comparison of single and two-phase anaerobic digestion. Waste Biomass Valori. 2019. https://doi.org/10.1007/s12649-019-00902-8.

24. Muralidharan V, Arokianathan MS, Balaraman M, Palanivel S. Tannery trimming waste based biodegradable bioplastic: facile synthesis and characterization of properties. Polym Test. 2020. https://doi.org/10.1016/j. polymertesting.2019.106250.

25. Sartore L, Schettini E, Palma L, Brunetti G, Cocozza C, Vox G. Effect of hydrolyzed protein-based mulching coatings on the soil properties and productivity in a tunnel greenhouse crop system. Sci Total Environ. 2018. https://doi.org/10.1016/j.scitotenv.2018.07.259.

26. Masilamani D, Srinivasan V, Ramachandran RK, Gopinath A, Madhan B, Saravanan P. Sustainable packaging materials from tannery trimming solid waste: A new paradigm in wealth from waste approaches. J Clean Prod. 2017. https://doi.org/10.1016/j.jclepro.2017.06.200.

27. Palani $Y$, Jonnalagadda RR, Nishter NF. Adsorption on activated carbon derived from tannery fleshing waste: adsorption isotherms, thermodynamics, and kinetics. Environ Prog Sustain Energy. 2017. https:// doi.org/10.1002/ep.12637.

28. Gomes CS, Piccin JS, Gutterres M. Optimizing adsorption parameters in tannery-dye-containing effluent treatment with leather shaving waste. Process Saf Environ Prot. 2016. https://doi.org/10.1016/j.psep.2015.10.013.

29. Piccin JS, Gomes CS, Feris LA, Gutterres M. Kinetics and isotherms of leather dye adsorption by tannery solid waste. Chem Eng J. 2012. https://doi.org/ 10.1016/j.cej.2011.12.013.

30. Olle M. Review: vermicompost, its importance and benefit in agriculture. J Agric Sci. 2019. https://doi.org/10.15159/jas.19.19.

31. Malafaia G, Araújo FG, Estrela DC, Guimarães ATB, Leandro WM, Rodrigues ASL. Corn production in soil containing in natura tannery sludge and irrigated with domestic wastewater. Agric Water Manage Qual. 2016. https://doi.org/10.1016/j.agwat.2015.09.018.

32. Nabavinia F, Emami H, Astaraee A, Lakzian A. Effect of tannery wastes and biochar on soil chemical and physicochemical properties and growth traits of radish. Int Agrophys. 2015. https://doi.org/10.1515/INTAG-2015-0040.

33. Jiang H, Liu J, Han W. The status and developments of leather solid waste treatment: a mini-review. Waste Manag Res. 2016. https://doi.org/10.1177/ $0734242 \times 16633772$

34. Zhuo N, Lan Y, Yang W, Yang Z, Li X, Zhou X, Liu Y, Shen J, Zhang X. Adsorption of three selected pharmaceuticals and personal care products (PPCPs) onto MIL-101 (Cr)/natural polymer composite beads. Sep Purif Technol. 2017. https://doi.org/10.1016/j.seppur.2016.12.041.

35. Chingombe P, Saha B, Wakeman RJ. Surface modification and characterisation of a coal-based activated carbon. Carbon. 2005. https://doi. org/10.1016/j.carbon.2005.06.021.

36. Rigueto CVT, Nazari MT, De Souza CF, Cadore JS, Brião VB, Piccin JS. Alternative techniques for caffeine removal from wastewater: an overview of opportunities and challenges. J Water Process Eng. 2020. https://doi.org/ 10.1016/j.jwpe.2020.101231.

37. Kantarli IC, Yanik J. Use of waste sludge from the tannery industry. Energy Fuel. 2009. https://doi.org/10.1021/ef8011068.

38. Piccin JS, Feris LA, Cooper M, Gutterres M. Dye adsorption by leather waste: mechanism diffusion, nature studies, and thermodynamic data. J Chem Eng. 2013. https://doi.org/10.1021/je301076n.

39. Arcibar-Orozco JA, Barajas-Elias BS, Caballero-Briones F, Nielsen L, RangelMendez JR. Hybrid carbon nanochromium composites prepared from chrome-tanned leather shavings for dye adsorption. Water Air Soil Pollut. 2019. https://doi.org/10.1007/s11270-019-4194-x.

40. Mella B, Benvenuti J, Oliveira RF, Gutterres M. Preparation and characterization of activated carbon produced from tannery solid waste applied for tannery wastewater treatment. Environ Sci Pollut. 2019. https:// doi.org/10.1007/s11356-019-04161-x.

41. Piccin JS, Guterres M, Salau NPG, Dotto GL. Mass transfer models for the adsorption of acid red 357 and acid black 210 by tannery solid wastes. Adsorpt Sci Technol. 2017. https://doi.org/10.1177/0263617416675624.

42. Piccin JS, Gomes CS, Mella B, Gutterres M. Color removal from real leather dyeing effluent using tannery waste as an adsorbent. J Environ Chem Eng. 2016. https://doi.org/10.1016/j.jece.2016.01.010.

43. Montoya-Suarez S, Colpas-Castillo F, Meza-Fuentes E, Rodríguez-Ruiz J, Fernandez-Maestre R. Activated carbons from waste of oil-palm kernel shells, sawdust and tannery leather straps and application to chromium (VI), phenol, and methylene blue dye adsorption. Water Sci Technol. 2016. https://doi.org/10.2166/wst.2015.293.

44. Anandkumar J, Mandal B. Adsorption of chromium (VI) and Rhodamine B by surface modified tannery waste: kinetic, mechanistic and thermodynamic studies. J Hazard Mater. 2011. https://doi.org/10.1016/j. jhazmat.2010.11.104.

45. Dallago RM, Smaniotto A, Oliveira LCAD. Solid waste from tanneries as adsorbent for the removal of dyes in aqueous medium. Quim Nova. 2005. https://doi.org/10.1590/S0100-40422005000300013.

46. Fathima NN, Aravindhan R, Rao RJ, Nair BU. Utilization of organically stabilized proteinous solid waste for the treatment of coloured wastewater. J Chem Technol Biotechnol. 2009. https://doi.org/10.1002/jctb.2186.

47. Cooney DO. Adsorption design for wastewater treatment. Florida: CRC press; 1998.

48. Işler A, Sundu S, Tüter M, Karaosmanoğlu F. Transesterification reaction of the fat originated from solid waste of the leather industry. Waste Manag. 2010. https://doi.org/10.1016/j.wasman.2010.06.005

49. Ramos L, Fernandes R, Crispim A, Ramalho E, Caetano N, Silva P. Biodiesel production from leather industry wastes. In: Proceedings of the 10th International Chemical and Biological Engineering Conference; 2008.

50. Adewale P, Dumont MJ, Ngadi M. Recent trends of biodiesel production from animal fat wastes and associated production techniques. Renew Sust Energ. 2015. https://doi.org/10.1016/j.rser.2015.02.039.

51. Kolomazník K, Pecha J, Barinova M, Šánek L, Furst T, Janacova D. Potential of tannery fleshings in biodiesel production and mathematical modeling of the fleshing pre-treatment. Int J Math Comput Simul. 2012;6:456-64.

52. Kubendran D, Salma Aathika AR, Amudha T, Thiruselvi D, Yuvarani M, Sivanesan S. Utilization of leather fleshing waste as a feedstock for sustainable biodiesel production. Energy Sources. 2017. https://doi.org/10. 1080/15567036.2017.1349218. 
53. Alptekin E, Canakci M, Sanli H. Evaluation of leather industry wastes as a feedstock for biodiesel production. Fuel. 2012. https://doi.org/10.1016/j.fuel. 2011.08.055.

54. Bhale PV, Deshpande NV, Thombre SB. Improving the low temperature properties of biodiesel fuel. Renew Energy. 2009. https://doi.org/10.1016/j. renene.2008.04.037.

55. Altun S, Yasar F. Biodiesel production from leather industry wastes as an alternative feedstock and its use in diesel engines. Energy Explor Exploit 2013. https://doi.org/10.1260/0144-5987.31.5.759.

56. Getahun E, Gabiyye N. Experimental investigation and characterization of biodiesel production from leather industry fleshing wastes. Int J Renew Sust Energ. 2013; doi:https://doi.org/10.11648/j.jirse.20130203.17.

57. Bondrea DA, Mocanu CR, Lazaroiu G, Maruntalu O, Stan AN, Toader MM. Energy recovering from tanneries by biodiesel production. In: 4th International conference on thermal equipment, renewable energy and rural development; 2015.

58. ANP - National Agency of Petroleum, Natural Gas and Biofuels. Brazilian resolution $n^{\circ}$ 4. 2010. http://legislacao.anp.gov.br/?path=legislacao-anp/ resol-anp/2010/fevereiro\&item=ranp-4-2010. Accessed 22 Feb 2020.

59. ASTM D 6751: Specification for biodiesel (B100). 2007. https://www.ag.ndsu. edu/agmachinery/documents/pdf/biodiesel\%20specifications\%203-2007.pdf. Accessed 1 Apr 2020.

60. EN 14214: Biodiesel Standards \& Properties. 2012. https://dieselnet.com/ tech/fuel_biodiesel_std.php\#cet. Accessed 2 Apr 2020.

61. ASTM D 6304 - 16e1. Standard test method for determination of water in petroleum products, lubricating oils, and additives by coulometric Karl Fischer Titration. Disponible at: https://www.astm.org/Standards/D6304.htm Acessed 21 Mar 2020.

62. ASTM D 874: RANP 4. 2010. http://legislacao.anp.gov.br/?path=legislacao-anp/ resol-anp/2010/fevereiro\&item=ranp-4\%2D\%2D2010. Accessed 13 Mar 2020.

63. ASTM D 4530: RANP 48. 2007. http://legislacao.anp.gov.br/?path=legislacaoanp/resol-anp/2007/dezembro\&item=ranp-48\%2D\%2D2007. Accessed 13 Mar 2020.

64. Mohamed AG, Nageh KA. Impact of nanotechnology on biogas production: a mini-review. Renew Sust Energ Rev. 2015. https://doi.org/10.1016/ jrser201505073.

65. Dalkılıc K, Ugurlu A. Biogas production from chicken manure at different organic loading rates in a mesophilic-thermopilic two stage anaerobic system. J Biosci Bioeng. 2015. https://doi.org/10.1016/jjbiosc201501021.

66. Belostotskiy DE, Ziganshina EE, Siniagina M, Boulygina EA, Miluykov VA, Ziganshin AM. Impact of the substrate loading regime and phosphoric acid supplementation on performance of biogas reactors and microbial community dynamics during anaerobic digestion of chicken wastes. Bioresour Technol. 2015. https://doi.org/10.1016/jbiortech201506066.

67. Pessuto J, Scopel BS, Perondi D, Godinho M, Dettmer A. Enhancement of biogas and methane production by anaerobic digestion of swine manure with addition of microorganisms isolated from sewage sludge. Process Saf Environ Prot. 2016. https://doi.org/10.1016/jpsep201608020.

68. Kameswari KSB, Kalyanaraman C, Umamaheswari B, Thanasekaran K. Enhancement of biogas generation during co-digestion of tannery solid wastes through optimization of mix proportions of substrates. Clean Techn Environ Policy. 2014. https://doi.org/10.1007/s1009801307063.

69. Bernat K, Zielińska M, Cydzik-Kwiatkowska A, Wojnowska-Baryła I. Biogas production from different size fractions separated from solid waste and the accompanying changes in the community structure of methanogenic Archaea. Biochem Eng J. 2015. https://doi.org/10.1016/jbej201504011.

70. Christy PM, Gopinath LR, Divya D. A review on anaerobic decomposition and enhancement of biogas production through enzymes and microorganisms. Renew Sust Energ Rev. 2014. https://doi.org/10.1016/ jrser201403010.

71. Mavrodin ME, Lazaroiu G. Experimental research on combustion of biogas obtained through anaerobic fermentation of tanneries wastes. Sci Bull "Politeh" Univ Bucharest Ser B. 2018;80:105-16

72. Agustini CB, da Fontoura JT, Mella B, Gutterres M. Evaluating co-substrates to supplement biogas production from tannery solid waste treatmentcattle hair, microalgae biomass, and silicone. Biofuels Bioprod Biorefin. 2018. https://doi.org/10.1002/bbb1929.

73. Bavaresco L, Perondi D, Dettmer A, Wang YZ. Steam explosion utilization as pre-treatment of chrome leather waste in order to produce biogas. In: 33th international union of leather technologists and chemists societies congress; 2015.
74. Kameswari KSB, Kalyanaraman C, Thanasekaran K. Effect of ozonation and ultrasonication pretreatment processes on co-digestion of tannery solid wastes. Clean Techn Environ Policy. 2011. https://doi.org/10.1007/ s1009801003340.

75. Kameswari KSB, Kalyanaraman C, Porselvam S, Thanasekaran K. Optimization of inoculum to substrate ratio for bio-energy generation in co-digestion of tannery solid wastes. Clean Techn Environ Policy. 2012. https://doi.org/10. 1007/s100980110391z

76. Kanchinadham SBK, Kalyanaraman C, Kumarasamy T. Optimization of organic load for co-digestion of tannery solid waste in semi-continuous mode of operation. Clean Techn Environ Policy. 2015. https://doi.org/10. 1007/s1009801408264.

77. Kameswari SBK, Kalyanaraman C, Porselvam S, Thanasekaran K. Enhancement of biogas generation by addition of lipase in the co-digestion of tannery solid wastes. Clean Soil Air Water. 2011. https://doi.org/10.1002/ clen201000408.

78. Zupančič GD, Jemec A. Anaerobic digestion of tannery waste: semi continuous and anaerobic sequencing batch reactor processes. Bioresour Technol. 2010. https://doi.org/10.1016/jbiortech200907028.

79. Li Y, Park SY, Zhu J. Solid-state anaerobic digestion for methane production from organic waste. Renew Sust Energ Rev. 2011. https://doi.org/10.1016/ jrser201007042.

80. Golub NB, Shinkarchuk MB, Shinkarchuk AB, Xinhua SH, Ying Z, Kozlovets $\mathrm{OA}$. Problematic issues in biogas production for the use of fat-containing leather in the leather industry. Innov Biosyst Bioeng. 2019. https://doi.org/ 10.20535/ibb201934185425.

81. Plastic Oceans: The Plastic Oceans Initiative. https://plasticoceans.org/. 2020. Accessed 22 Mar 2020.

82. Giri J, Adhikari R. Biodegradable copolyester-based natural fibers-polymer composites: morphological, mechanical, and degradation behavior. In: Katiyar V, Kumar A, Mulchandani N, editors. Advances in sustainable polymers. Singapore: Springer; 2020. p. 289-319.

83. Winton DJ, Anderson LG, Rocliffe S, Loiselle S. Macroplastic pollution in freshwater environments: focusing public and policy action. Sci Total Environ. 2020. https://doi.org/10.1016/jscitotenv2019135242.

84. Carissimi M, Flôres HS, Rech R. Effect of microalgae addition on active biodegradable starch film. Algal Res. 2018. https://doi.org/10.1016/ jalgal201804001.

85. Rosseto M, Krein DDC, Balbé NP, Dettmer A. Starch-gelatin film as an alternative to the use of plastics in agriculture: a review. J Sci Food Agric. 2019. https://doi.org/10.1002/jsfa.9944.

86. Scopel BS, Ribeiro ME, Dettmer A, Baldasso C. Cornstarch-gelatin films: commercial gelatin versus chromed leather waste gelatin and evaluation of drying conditions. J Polym Environ. 2018. https://doi.org/10.1007/s10924017-1097-z.

87. Rosseto M. Enzymatic and antimicrobial treatment in corn starch and gelatin films recovered from chromium (III)-tanned wastes: Dissertation, University of Passo Fundo; 2020. https://secure.upf.br/pdf/202 OMarieliRosseto.pdf.

88. Dang $X$, Shan Z, Chen H. Biodegradable films based on gelatin extracted from chrome leather scrap. Int J Biol Macromol. 2018. https://doi.org/10. 1016/j.ijbiomac.2017.09.068.

89. Erciyes A, Ocak B. Physico-mechanical, thermal, and ultraviolet light barrier properties of collagen hydrolysate films from leather solid wastes incorporated with nano $\mathrm{TiO}_{2}$. Polym Compos. 2019. https://doi.org/10.1002/ pc.25340.

90. Ocak B. Film-forming ability of collagen hydrolysate extracted from leather solid wastes with chitosan. Environ Sci Pollut Res. 2017. https://doi.org/10. 1007/s11356-017-0843-z.

91. Gil CS, Gil VS, Carvalho SM, Silva GR, Magalhães JT, Oréfice RL, Mansur A, Patricio PSO, Oliveira LC. Recycled collagen films as biomaterials for controlled drug delivery. New J Chem. 2016. https://doi.org/10.1039/ c6nj00674d.

92. Dang X, Shan Z, Chen $\mathrm{H}$. The preparation and applications of one biodegradable liquid film mulching by oxidized corn starch-gelatin composite. Appl Biochem Biotechnol. 2016. https://doi.org/10.1007/s12010016-2142-4

93. Ruthrof KX, Steel E, Misra S, McComb J, O'hara G, Hardy GESJ, Howieson J. Transitioning from phosphate mining to agriculture: responses to urea and slow release fertilizers for Sorghum bicolor. Sci Total Environ. 2018. https:// doi.org/10.1016/j.scitotenv.2017.12.104. 
94. Barylska AZ, Plucinska GL. Populus x canescens grown on Cr-rich tannery waste: comparison of leaf and root biochemical and proteomic responses. Plant Physiol Biochem. 2015. https://doi.org/10.1016/j.plaphy.2015.02.014.

95. Ravindran B, Wong JWC, Selvam A, Murugesan K, Mohanapriya D, Sekaran $\mathrm{G}$. Influence of fermented tannery solid waste on morphological, biochemical, yield and nutritional responses of tomato plants. Environ Sci Pollut Res. 2015. https://doi.org/10.1007/s11356-014-3629-6.

96. Silva JDC, Leal TTB, Araújo ASF, Araujo RM, Gomes RLF, Melo WJ, Singh RP. Effect of different tannery sludge compost amendment rates on growth, biomass accumulation and yield responses of Capsicum plants. Waste Manag. 2010. https://doi.org/10.1016/j.wasman.2010.03.011.

97. Ravindran B, Won JWC, Selvam A, Sekaran G. Influence of microbial diversity and plant growth hormones in compost and vermicompost from fermented tannery waste. Bioresour Technol. 2016. https://doi.org/10.1016/j. biortech.2016.03.032.

98. Nunes RR, Pigatinga LBF, Oliveira TS, Bontempi RM, Rezende MOO. Vermicomposted tannery wastes in the organic cultivation of sweet pepper: growth, nutritive value and production. Int J Recycl Org Waste Agric. 2018. https://doi.org/10.1007/s40093-018-0217-7.

99. Agency for Toxic Substances and Disease Registry (ATSDR). 2012. Toxicological profile for Chromium. https://www.atsdr.cdc.gov/PHS/PHS. asp?id=60\&tid=17. Accessed 30 Mar 2020.

100. Ravindran B, Lee SR, Chang SW, Nguyen DD, Chung WJ, Balasubramanian B, Mupambwa HA, Arasu MV, Al-dhabi NA, Sekaran G. Positive effects of compost and vermicompost produced from tannery wasteanimal fleshing on the growth and yield of commercial crop-tomato (Lycopersicon esculentum L.) plant. J Environ Manage. 2019. https://doi.org/10.1016/j. jenvman.2018.12.100.

101. Nogueira FGE, Prado NT, Oliveira LCA, Bastos ARR, Lopes JH, Carvalho JG. Incorporation of mineral phosphorus and potassium on leather waste (collagen): A new $\mathrm{N}_{\text {collagen }}$ PK-fertilizer with slow liberation. J Hazard Mater. 2010. https://doi.org/10.1016/j.jhazmat.2009.11.040.

102. Azeem B, KuShaari K, Man ZB, Basit A, Thanh TH. Review on materials \& methods to produce controlled release coated urea fertilizer. J Control Release. 2014. https://doi.org/10.1016/j.jconrel.2014.02.020.

103. Treinyt J, Grazulevicien V, Paleckiene R, Ostrauskait J, Cesonien L. Biodegradable polymer composites as coating materials for granular fertilizers. J Polym Environ. 2018. https://doi.org/10.1007/s10924-017-0973-X.

104. Dang $X$, Yang M, Zhang B, Chen H, Wang Y. Recovery and utilization of collagen protein powder extracted from chromium leather scrap waste. Environ Sci Pollut Res. 2019. https://doi.org/10.1007/s11356-019-04226-x.

105. Ali S, Rizwan M, Waqas A, Hussain MB, Hussain A, Liu S, Alqarawi AA, Hashem A, Allah EFA. Fulvic acid prevents chromium-induced morphological, photosynthetic, and oxidative alterations in wheat irrigated with tannery wastewater. J Plant Growth Regul. 2018. https://doi.org/10. 1007/s00344-018-9843-6.

106. Benlboukht F, Fels LE, Bouamri R, Amir S, Hafidi M. Assessment of fulvic acid-like fractions during tannery waste composting. Compost Sci Util. 2016. https://doi.org/10.1080/1065657X.2015.1137252.

107. Yoseph Z, Christopher JG, Demessie BA, Selvi AT, Sreeram KJ, Rao JR. Extraction of elastin from tannery wastes: a cleaner technology for tannery waste management. J Clean Prod. 2020. https://doi.org/10.1016/j.jclepro. 2019.118471.

108. Bahrambeygi H, Sabetzadeh N, Rabbi A, Nasouri K, Shoushtari AM, Babaei MR. Nanofibers (PU and PAN) and nanoparticles (Nanoclay and MWNTs) simultaneous effects on polyurethane foam sound absorption. J Polym Res. 2013. https://doi.org/10.1007/s10965-012-0072-6.

109. Selvaraj S, Jeevan V, Jonnalagadda RR, Fathima NN. Conversion of tannery solid waste to sound absorbing nanofibrous materials: a road to sustainability. J Clean Prod. 2019. https://doi.org/10.1016/j.jclepro.2018.12.144.

110. Pei Y, Chu S, Zheng Y, Zhang J, Liu H, Zheng X, Tang K. Dissolution of collagen fibers from tannery solid wastes in 1-Allyl-3-methylimidazolium chloride and modulation of regenerative morphology. ACS Sustain Chem Eng. 2018. https://doi.org/10.1021/acssuschemeng.8b05428.

111. Zhang L, Li Z, Xiao Y, Liu Z, Pei Y, Wang G, Tang K. Dissolution of collagen fibers from tannery solid wastes in salt aqueous solutions: Hofmeister series evaluation. J Chem Technol Biotechnol. 2020. https://doi.org/10.1002/jctb. 6311.

112. Masilamani D, Madhan B, Shanmugam G, Palanivel S, Narayan B. Extraction of collagen from raw trimming wastes of tannery: a waste to wealth approach. J Clean Prod. 2016. https://doi.org/10.1016/j.jclepro.2015.11.087.
113. Sasia AA, Sang P, Onyuka A. Recovery of collagen hydrolysate from chrome leather shaving tannery waste through two-step hydrolysis using magnesium oxide and bating enzyme. SLTC J. 2019;103:80-4.

114. Cao J, Lv YH, Chang GY, Tang KY. Glutaralde hyde modification of collagen hydrolysate obtained from chrome shavings. J Am Leather Chem Assoc. 2005:100:265-72.

115. Catalina M, Antunes APM, Attenburrow G, Cot J, Covington AD, Phillips PS. Sustainable management of waste-reduction of the chromium content of tannery solid waste as a step in the cleaner production of gelatin. J Solid Waste Technol. 2007;33:43-50.

116. Rosseto M, Rigueto CVT, Krein DDC, Balbé NP, Massuda LA, Dettmer A. Biodegradable polymers: opportunities and challenges. In: Sand A, Zaki E, Zaki E, editors. Bio-based polymers. London: IntechOpen; 2019.

117. Reich T, Rossberg A, Hennig C, Reich G. Characterization of chromium complexes in chrome tannins, leather, and gelatin using extended X-ray absorption fine structure (EXAFS) spectroscopy. J Am Leather Chem Assoc. 2001:96:133-47.

118. Scopel BS, Restelatto D, Baldasso C, Dettmer A, Santana RMC. Steam explosion in alkaline medium for gelatine extraction from chromium-tanned leather wastes: time reduction and process optimization. Environ Technol. 2018. https://doi.org/10.1080/09593330.2018.1551430.

119. Kluska J, Turzyński T, Kardaś D. Experimental tests of co-combustion of pelletized leather tannery wastes and hardwood pellets. Waste Manag. 2018. https://doi.org/10.1016/j.wasman.2018.07.023.

120. Kluska J, Turzyński T, Ochnio M, Kardaś D. Characteristics of ash formation in the process of combustion of pelletised leather tannery waste and hardwood pellets. Renew Energy. 2020. https://doi.org/10.1016/j.renene. 2019.10.122.

121. Onukak IE, Mohammed-Dabo IA, Ameh AO, Okoduwa SI, Fasanya OO. Production and characterization of biomass briquettes from tannery solid waste. Recycling. 2017. https://doi.org/10.3390/recycling2040017.

122. Hashem MA, Nur-A-Tomal MS. Tannery solid waste valorization through composite fabrication: a waste-to-wealth approach. Environ Prog Sust Energ. 2018. https://doi.org/10.1002/ep.12860.

123. Ruiz MR, Budemberg ER, da Cunha GP, Bellucci FS, da Cunha HN, Job AE. An innovative material based on natural rubber and leather tannery waste to be applied as antistatic flooring. J Appl Polym Sci. 2015. https://doi.org/ 10.1002/app.41297.

124. Dweck J, Buchler PM, Cartledge FK. The effect of different bentonites on cement hydration during solidification/stabilization of tannery wastes. J Therm Anal Calorim. 2001. https://doi.org/10.1023/A:A1011591401483.

125. Dweck J, Buchler PM, Coelho ACV, Cartledge FK. Solidification/ stabilization of a tannery waste with blended cement and wyoming bentonite. J Environ Sci Health Part A. 2000. https://doi.org/10.1080/ 10934520009376998.

126. Yatribi A, Boukhars L, Nejmeddine A. A contribution to the industrial valorization of tannery waste: the case of cement industry; contribution a la valorisation industrielle des dechets de tanneries: cas de la cimenterie. Ann Chim Sci Mat. 2001;26:107-12.

127. Sanchez-Olivares G, Sanchez-Solis A, Calderas F, Alongi J. Keratin fibres derived from tannery industry wastes for flame retarded PLA composites. Polym Degrad Stab. 2017. https://doi.org/10.1016/j.polymdegradstab.2017. 04.011.

128. Yuvaraj P, Rao JR, Fathima NN, Natchimuthu N, Mohan R. Complete replacement of carbon black filler in rubber sole with $\mathrm{CaO}$ embedded activated carbon derived from tannery solid waste. J Clean Prod. 2018 https://doi.org/10.1016/j.jclepro.2017.09.188.

129. Yaohui Y, Yurhang Z, Yishan L, Bi S, Xuepin L. Utilization of tannery solid waste dry strength additive for papermaking. J Am Leather Chem Assoc. 2013;108:250-6.

130. Abreu MA, Toffoli SM. Characterization of a chromium-rich tannery waste and its potential use in ceramics. Ceram Int. 2009. https://doi.org/10.1016/j. ceramint.2008.12.011.

131. Fang Z, Zhang J, Liu B, Du G, Chen J. Biochemical characterization of 405 three keratinolytic enzymes from Stenotrophomonas maltophilia BBE11-1 for 406 biodegrading keratin wastes. Int Biodeter Biodeger. 2013;82:166-72.

132. Rao MB, Tanksale AM, Ghatge MS, Deshpande W. Molecular and biotechnological aspects of microbial proteases. Microbiol Mol Biol Rev. 1998;62:597-635.

133. Rai SK, Mukherjee AK. Statistical optimization of production, purification and industrial application of a laundry detergent and organic solvent-stable 
subtilisin-like serine protease (Alzwiprase) from Bacillus subtilis DM-04. Biochem Eng J. 2010. https://doi.org/10.1016/j.bej.2009.09.007.

134. Ravindran B, Wong JW, Selvam A, Thirunavukarasu K, Sekaran G. Microbial biodegradation of proteinaceous tannery solid waste and production of a novel value added product-Metalloprotease. Bioresour Technol. 2016;217: 150-6. https://doi.org/10.1016/j.biortech.2016.03.033.

135. Kumar AG, Venkatesan R, Prasad BR, Swarnalatha S, Sekaran G. Utilization of tannery solid waste for protease production by Synergistes sp. in solid-state fermentation and partial protease characterization. Eng Life Sci. 2009. https://doi.org/10.1002/elsc.200700040.

136. Puhazhselvan P, Aparna R, Ayyadurai N, Gowthaman MK, Saravanan P, Kamini NR. Enzyme based cleaner process for enhanced recovery of lipids from tannery fleshing waste. J Clean Prod. 2017. https://doi.org/10.1016/j. jclepro.2016.12.148.

137. Manikandan A, Polani RB, Kamini NR. Solid state fermentation of lipase production from Aspergillus Niger using tannery solid waste. Int J Pure Appl Math. 2015;7:8804-16.

138. Manikandan A, Babu PBR. Submerged fermentatition of Aspergillus Niger lipase production by using tannery solid waste. Int J Pure Appl Math. 2018; 199:1749-61.

139. De Medeiros IP, Rozental S, Costa AS, Macrae A, Hagler AN, Ribeiro JR, Vermelho AB. Biodegradation of keratin by Trichosporum loubieri RC-S6 isolated from tannery/leather waste. Int Biodeterior Biodegrad. 2016. https:// doi.org/10.1016/j.ibiod.2016.08.006.

140. Ghori MI, Iqbal MJ, Hameed A. Characterization of a novel lipase from Bacillus sp. isolated from tannery wastes. Braz I Microbiol. 2011. https://doi. org/10.1590/S1517-83822011000100003.

141. Joshi BH. Purification and characterization of a novel protease from Bacillus firmus Tap5 isolated from tannery waste. J Appl Sci Res. 2010:1068-76.

142. Alam MJ, Amin MR, Samad MA, Islam MA, Wadud MA. Use of tannery wastes in the diet of broiler. Asian Australas J Anim Sci. 2002. https://doi. org/10.5713/ajas.2002.1773.

143. Alam J, Hossain M, Beg AH, Nam KC, Lee SS. Effects of tannery wastes on the fattening of growing cattle, carcass, and meat quality. Food Sci Anim Resour. 2010. https://doi.org/10.5851/kosfa.2010.30.2.190.

144. Chaudhary R, Pati A. Poultry feed based on protein hydrolysate derived from chrome-tanned leather solid waste: creating value from waste. Environ Sci Pollut Res. 2016. https://doi.org/10.1007/s1 1356-016-6302-4.

145. Jini R, Bijinu B, Baskaran V, Bhaskar N. Utilization of solid wastes from tanneries as possible protein source for feed applications: acute and subacute toxicological studies to assess safety of products prepared from delimed tannery fleshings. Waste Biomass Valori. 2016. https://doi.org/10 1007/S12649-015-9463-3.

\section{Publisher's Note}

Springer Nature remains neutral with regard to jurisdictional claims in published maps and institutional affiliations.

\section{Submit your manuscript to a SpringerOpen ${ }^{\circ}$ journal and benefit from:}

- Convenient online submission

- Rigorous peer review

- Open access: articles freely available online

- High visibility within the field

- Retaining the copyright to your article

Submit your next manuscript at $\boldsymbol{\nabla}$ springeropen.com 